\title{
Review Article \\ Heavy Metal Stress and Some Mechanisms of Plant Defense Response
}

\author{
Abolghassem Emamverdian, ${ }^{1,2}$ Yulong Ding, ${ }^{1,3}$ Farzad Mokhberdoran, ${ }^{4}$ and Yinfeng Xie ${ }^{1,2}$ \\ ${ }^{1}$ Center of Modern Forestry in Southern China, Nanjing Forestry University, Nanjing 210037, China \\ ${ }^{2}$ College of Biology and the Environment, Nanjing Forestry University, Nanjing 210037, China \\ ${ }^{3}$ Bamboo Research Institute, Nanjing Forestry University, Nanjing 210037, China \\ ${ }^{4}$ Department of Agronomy and Plant Breeding, Faculty of Agriculture, Islamic Azad University, Mashhad Branch, \\ Mashhad 9187147578, Iran \\ Correspondence should be addressed to Yulong Ding; ylding@vip.163.com
}

Received 14 October 2014; Revised 2 January 2015; Accepted 5 January 2015

Academic Editor: Luca Sebastiani

Copyright (C) 2015 Abolghassem Emamverdian et al. This is an open access article distributed under the Creative Commons Attribution License, which permits unrestricted use, distribution, and reproduction in any medium, provided the original work is properly cited.

\begin{abstract}
Unprecedented bioaccumulation and biomagnification of heavy metals (HMs) in the environment have become a dilemma for all living organisms including plants. HMs at toxic levels have the capability to interact with several vital cellular biomolecules such as nuclear proteins and DNA, leading to excessive augmentation of reactive oxygen species (ROS). This would inflict serious morphological, metabolic, and physiological anomalies in plants ranging from chlorosis of shoot to lipid peroxidation and protein degradation. In response, plants are equipped with a repertoire of mechanisms to counteract heavy metal (HM) toxicity. The key elements of these are chelating metals by forming phytochelatins (PCs) or metallothioneins (MTs) metal complex at the intra- and intercellular level, which is followed by the removal of HM ions from sensitive sites or vacuolar sequestration of ligand-metal complex. Nonenzymatically synthesized compounds such as proline (Pro) are able to strengthen metal-detoxification capacity of intracellular antioxidant enzymes. Another important additive component of plant defense system is symbiotic association with arbuscular mycorrhizal (AM) fungi. AM can effectively immobilize HMs and reduce their uptake by host plants via binding metal ions to hyphal cell wall and excreting several extracellular biomolecules. Additionally, AM fungi can enhance activities of antioxidant defense machinery of plants.
\end{abstract}

\section{Introduction}

Anthropogenic perturbations of biosphere manifested in a broad array of global phenomena including accelerated rate of industrialization, intensive agriculture, and extensive mining accompanied by burgeoning population and rapid urbanization have not only wreaked the havoc on the availability of natural resources but also caused widespread and grave contamination of essential components of life on the planet. Of the implications of human-induced disturbance of natural biogeochemical cycles, accentuated accumulation of heavy metals (HMs) is a problem of paramount importance for ecological, nutritional, and environmental reasons [1, 2]. HMs belong to group of nonbiodegradable, persistent inorganic chemical constituents with the atomic mass over
20 and the density higher than $5 \mathrm{~g} \cdot \mathrm{cm}^{-3}$ that have cytotoxic, genotoxic, and mutagenic effects on humans or animals and plants through influencing and tainting food chains, soil, irrigation or potable water, aquifers, and surrounding atmosphere [3-6]. There are two kinds of metals found in soils, which are referred to as essential micronutrients for normal plant growth ( $\mathrm{Fe}, \mathrm{Mn}, \mathrm{Zn}, \mathrm{Cu}, \mathrm{Mg}, \mathrm{Mo}$, and $\mathrm{Ni}$ ) and nonessential elements with unknown biological and physiological function $\mathrm{Cd}, \mathrm{Sb}, \mathrm{Cr}, \mathrm{Pb}, \mathrm{As}, \mathrm{Co}, \mathrm{Ag}$, Se, and $\mathrm{Hg})[5,7-9]$. Both underground and aboveground surfaces of plants are able to receive HMs [10]. The essential elements play a pivotal role in the structure of enzymes and proteins. Plants require them in tiny quantities for their growth, metabolism, and development; however, the concentration of both essential and nonessential metals is one single important 
factor in the growing process of plants so that their presence in excess can lead to the reduction and inhibition of growth in plants [11]. HMs at toxic levels hamper normal plant functioning and act as an impediment to metabolic processes in a variety of ways, including disturbance or displacement of building blocks of protein structure, which arises from the formation of bonds between HMs and sulfhydryl groups [12], hindering functional groups of important cellular molecules [13], superseding or disrupting functionality of essential metals in biomolecules such as pigments or enzymes [2], and adversely affecting the integrity of the cytoplasmic membrane [14], resulting in the repression of vital events in plants such as photosynthesis, respiration, and enzymatic activities [13]. On the other hand, elevated levels of HMs are associated with the increased generation of reactive oxygen species (ROS), such as superoxide free radicals $\left(\mathrm{O}_{2}{ }^{--}\right)$, hydroxyl free radicals $\left(\mathrm{OH}^{\bullet-}\right)$, or non-free radical species (molecular forms) such as singlet oxygen $\left(\mathrm{O}_{2}{ }^{*}\right)$ and hydrogen peroxide $\left(\mathrm{H}_{2} \mathrm{O}_{2}\right)$ as well as cytotoxic compounds like methylglyoxal (MG), which can cause oxidative stress via disturbing the equilibrium between prooxidant and antioxidant homeostasis within the plant cells $[11,13,15]$. This condition implicates the causation of multiple deteriorative disorders such as, oxidation of protein and lipids, ion leakage, oxidative DNA attack, redox imbalance, and denature of cell structure and membrane, ultimately resulting in the activation of programmed cell death (PCD) pathways $[1,3,5,16-18]$. Plants employ various inherent and extrinsic defense strategies for tolerance or detoxification whenever confronted with the stressful condition caused by the high concentrations of HMs. As a first step towards dealing with metal intoxication, plants adopt avoidance strategy to preclude the onset of stress via restricting metal uptake from soil or excluding it, preventing metal entry into plant root [19]. This can be achieved by some mechanisms such as immobilization of metals by mycorrhizal association, metal sequestration, or complexation by exuding organic compounds from root $[10,20]$. At next stage, if these strategies fail and HMs manage to enter inside plant tissues, tolerance mechanisms for detoxification are activated which include metal sequestration and compartmentalization in various intracellular compartments (e.g., vacuole) [10], metal ions trafficking, metal binding to cell wall, biosynthesis or accumulation of osmolytes andosmoprotectants, for example, proline (Pro), intracellular complexation or chelation of metal ions by releasing several substances, for example, organic acids, polysaccharides, phytochelatins (PCs), and metallothioneins (MTs) [20-23], and eventually if all these measures prove futile and plants become overwhelmed with toxicity of heavy metal (HM), activation of antioxidant defense mechanisms is pursued [24]. This review has attempted a comprehensive account of past developments and current trends using more than 235 articles in the research on HM poisoning in plants, exploring the response of vital growth, morphological, anatomical, production, and physiological parameters of plants to HM toxicity as well as investigating detoxifying roles of some defense mechanisms adopted by plants in the face of trace element excess. The study also focuses on underlying functions and detoxification capabilities of two important ligand peptides including PCs and MTs that are typically used by plants to enhance tolerance to HM toxicity. Moreover, another line of plant defense strategy to combat against toxicity of HMs which involves the utilization of primary metabolite molecule Pro and the instigation of AM symbiotic system as well as their possible collaboration with one another or with plant antioxidant system is discussed and surveyed. Lastly, some suggestions will be made in terms of pursuing ways to have a better understanding of metal-plant causality involving action and reaction between these two abiotic and biotic entities in everchanging natural environments and climate. Some directions for future works will also be provided.

\section{Effects of Some HMs on Plants}

Bioactive-metals, based on their physicochemical properties, are divided into two groups of redox-active metals such as $\mathrm{Cr}, \mathrm{Cu}, \mathrm{Mn}$, and $\mathrm{Fe}$ and non-redox active metals such as $\mathrm{Cd}, \mathrm{Ni}, \mathrm{Hg}, \mathrm{Zn}$, and $\mathrm{Al}[25,26]$. The redox metals can directly generate oxidative injury via undergoing HaberWeiss and Fenton reactions, which leads to the aforementioned production of ROS or oxygen free radicals species in plants, resulting in cell homeostasis disruption, DNA strand breakage, defragmentation of proteins, or cell membrane and damage to photosynthetic pigments, which may trigger cell death $[7,27]$. In contrast, non-redox active metals indirectly inflict oxidative stress via multiple mechanisms including glutathione depletion, binding to sulfhydryl groups of proteins [25], inhibiting antioxidative enzymes, or inducing ROS-producing enzymes like NADPH oxidases [28]. The basic criterion for the selection of HMs for this review study was based on their mode of action in biological system of plants, whether they are redox active or inactive metals in plant cells. Therefore, three metals $(\mathrm{Cu}, \mathrm{Cr}$, and $\mathrm{Mn})$ that are known for taking part in redox reactions in plants and three non-redox active metals $(\mathrm{Ni}, \mathrm{Zn}$, and $\mathrm{Al}$ ) are reviewed in detail to show how they impinge on plants despite possessing different redox states.

2.1. Chromium (Cr). It is well documented that $\mathrm{Cr}$ is a toxic agent for the growth and development of plants [29-31]. In addition, it is known as one of the causes of environmental pollution [32]. In plants, $\mathrm{Cr}$ is found in the forms of trivalent $\mathrm{Cr}^{3+}$ and hexavalent $\mathrm{Cr}^{6+}$ species, where the former is of lower toxicity than the latter. $\mathrm{Cr}$ is transported and accumulated via carrier ions such as sulfate or iron and is not directly absorbed by plants [32, 33]. Moreover, under reducing condition, $\mathrm{Cr}^{6+}$ is converted to its more toxic form $\mathrm{Cr}^{3+}$, which can indirectly influence and change soil $\mathrm{pH}$ to both alkalinity or acidity extremes, depending on prevailing condition in soil subsurface [34]. This phenomenon might perturb the nutrients bioavailability and their sorption by plants. The highest concentration of $\mathrm{Cr}$ occurs in the root rather than other parts of plants [35].

Immobilization of chromium in vacuole of plant root cells is suggested as a main reason for the excessive accumulation of this metal in roots [36, 37]. Cr drastically reduces seedling dry matter production and hampers the 
development of stems and leaves during plant early growth stage [37]. Chromium toxicity inhibits the cell division and elongation of plant roots, thus shortening the overall length of roots [38]. As a consequence, water and nutrient absorption processes are severely restricted, which can lead to the decreased shoot growth. Furthermore, the extended cell cycle is attributed to toxic presence of $\mathrm{Cr}$ in roots [39]. Fozia et al. [40] assessing effects of chromium on growth attributes of sunflower (Helianthus annuus L.) ascribed the observed decrease in root length to cell cycle extension triggered by $\mathrm{Cr}$ toxicity. $\mathrm{Cr}$ can cause damage to plants through manipulating some mechanisms that occur inside cell. Zou et al. [30] in an in vitro study observed that $\mathrm{Cr}$ reduced root growth of Amaranthus viridis L. This decrease was associated with cell division inhibition and imbalance of $\mathrm{Ca}^{2+}$ in cells caused by $\mathrm{Cr}$, disturbing the transport of calcium cation from plasma membrane into cytoplasm. Chromium is capable of creating metabolic disorders during seed germination by disrupting the events related to the conversion of food reservoirs into energy that are essential for the subsequent successful emergence and establishment of seedlings. In cowpea (Vigna sinensis (L.) savi ex Hassk) seeds, treated with different concentrations of $\mathrm{Cr}^{6+}$, amylase activity and total amount of sugar were markedly decreased, resulting in depression of germination characteristics [41]. Nagajyoti et al. [1] also reported that increased levels of $\mathrm{Cr}$ in different valence states were associated with concomitant decline in seed germination. This can be due to disruption in carbohydrate transfer into embryonic axis in seeds or a rise in protease activity [42]. Both antagonistic and synergistic interactions between chromium levels and content of different elements in parts of plants are observed. Samantaray et al. [43] reported that chromium is involved in interfering with the absorption or accumulation of a wide range of other metals or nutrients such as $\mathrm{Fe}, \mathrm{Mn}, \mathrm{Ca}, \mathrm{Mg}, \mathrm{K}$, and $\mathrm{P}$ in both aerial or root parts of plants, mostly leading to their reduced cellular or tissue concentration. Živković et al. [44] carried out a study on the effects of different trace metals on three Veronica species (Plantaginaceae) and found a high positive correlation between $\mathrm{Fe}$ and $\mathrm{Cr}$ concentration in plant tissues.

2.2. Aluminum ( $\mathrm{Al}$ ). $\mathrm{Al}$ is known as an inhibitory element for the growth of plants, especially in acidic soils with $\mathrm{pH}$ values as low as 5 or 5.5 where the most phytotoxic form of aluminum $\left(\mathrm{Al}^{3+}\right)$ is prevalent [45]. Although there is still no known or proven biological role for aluminum in plants, some reports demonstrate that $\mathrm{Al}$ at low concentrations may lead to the stimulation of plant growth [46]. A $2-3 \mu \mathrm{g} \cdot \mathrm{g}^{-1}$ aluminum threshold in soils with a pH below 5.5 is considered to be hazardous to most plants [47]. The primary target of $\mathrm{Al}$ toxicity is roots of plants where the accumulation of $\mathrm{Al}$ inflicts the inhibition of root growth in the space of minutes or hours [48]. It can increase the thickness of lateral roots and change their color to brown [49]. Reduction of root respiration and disturbances in the enzymatic regulation of sugar phosphorylation are also caused by $\mathrm{Al}$ toxicity [50]. The molecular events responsible for Al-induced root depression may include the attachment of $\mathrm{Al}$ to carboxylic groups of pectins in root cells [51], or the hindrance of cell division in roots by $\mathrm{Al}$ ions binding to DNA, which results in the enhanced structural rigidity of double helix in DNA and cell wall [52]. Al toxicity stress negatively affects aerial parts of plants, especially as a result of initial root damage [53], which hampers nutrient uptake ability of roots, resulting in nutritional deficiency [54] but the symptoms are not as conspicuous as those observed in roots [55].

The symptomatic effects of Al-induced stress on shoots, which are similar to phosphorus deficiency, may be stunting of leaves, purple discoloration on stems, leaves, and leaf veins followed by yellowing and dead leaf tips [56], and those that resemble calcium deficiency can be curling or rolling of young leaves and death of growing points or petioles [55]. The other visible indications of $\mathrm{Al}$ toxicity are the appearance of small necrotic spots on the border of young leaves and chlorosis in the margins and center of older leaves [53]. The reduction in stomatal aperture and decreased photosynthetic activity are also reported to be caused by Al toxicity [57]. Bhalerao and Prabhu [58] reported that Al toxicity in plants such as maize (Zea mays L.) and sorghum (Sorghum bicolor (L.) Moench) can lead to perturbation in the absorption and transportation of some major nutrients including $\mathrm{P}, \mathrm{K}$, $\mathrm{Ca}$, and $\mathrm{Mg}$. A range of morphological and physiological responses have been observed in crop plants when they are exposed to different levels of aluminum. Hossain et al. [59] studying two wheat (Triticum aestivum L.) cultivars varying in their degree of sensitivity to $\mathrm{Al}$ stress found that the length of root in Al-sensitive cultivar was conspicuously decreased. Moreover, $\mathrm{Al}$ stress especially in sensitive cultivar raised the amount of some cellular substances such as pectin and hemicelluloses. Batista et al. [60] observed that leaf sheaths of corn plants treated with different doses of $\mathrm{Al}$ had underdeveloped epidermal and cortical cells, which was accompanied by a decrease in the diameter of metaxylem and protoxylem in vascular bundle. At the ultrastructural level, alteration of chromatin configuration in nucleus and an increase in the size and frequency of nucleolar vacuoles are ascribed to $\mathrm{Al}$ stress [61].

2.3. Manganese $(\mathrm{Mn}) . \mathrm{Mn}$ is an essential micronutrient that plays a pivotal part in many metabolic and growth processes in plants including photosynthesis, respiration, and the biosynthesis of enzymes such as malic enzyme, isocitrate dehydrogenase, and nitrate reductase [62]. It is also a cofactor required for multiple plant enzymes, for example, Mndependent superoxide dismutase (MnSOD) [63]. Furthermore, manganese is involved in carbohydrate and nitrogen metabolism, synthesis of fatty acid, acyl lipids, and carotenoid as well as hormonal activation $[33,63,64]$. The contribution of manganese to the functionality of photosystem II (PSII) especially during the course of splitting of water molecules into oxygen [65] and its role in the protection of PSII from photo damage are of significant importance [66]. $\mathrm{Mn}^{2+}$ is the most stable and soluble form of manganese in the soil environment [67]. However, lower soil pH, less soil organic matter, and decreased redox potential increase the availability or toxicity of $\mathrm{Mn}^{2+}$ to plants $[67,68]$. Contrary to some 
elements such as aluminum or copper, there is a tendency for manganese to easily translocate form roots to the upper parts of plants. This mobility is the reason why symptoms of Mn toxicity are first visible in aerial organs of plants [69]. The appearance of visual features in plants affected by Mn toxicity varies with the type of plant species, plant age, temperature, and light level [70-72]. The symptoms may include crinkled leaves [73], darkening of leaf veins on older foliage [74], chlorosis and brown spots on aged leaves [75], and black specks on the stems [76]. Mn toxicity has been associated with a decreased $\mathrm{CO}_{2}$ assimilation but unaffected chlorophyll (Chl) level in Citrus grandis seedlings [77] and depleted Chl content in pea (Pisum sativum L.) [78] and soybean (Glycine $\max$ L.) [79], indicating diversity among plant species in response to $\mathrm{Mn}$ excess.

Combined effects of excessive manganese and light on plants have received particular attention in the literature. González et al. [70] examining the interactive effects of light intensity and Mn excess on two Mn-susceptible and tolerant genotypes of common bean (Phaseolus vulgaris L.) demonstrated that high light aggravated the toxic influence of $\mathrm{Mn}$, causing the plants to produce, respectively, a $270 \%$ and $130 \%$ more ascorbate peroxidase (APX) in leaves to cope with Mn toxicity. In maple trees (Acer platanoides) leaves exposed to intense sun light had more concentrations of Mn than shade leaves [80]. In contrast, Hajiboland and Hasani [81] working with rice (Oryza sativa L.) and sunflower found that although Mn toxicity depressed shoot and root growth, the intensification of light diluted concentration of $\mathrm{Mn}$ in these plants, ameliorating growth inhibition caused by $\mathrm{Mn}$ treatment. Wissemeier and Horst [82] in cowpea (Vigna unguiculata Walp) found that light intensity did not play any part in exacerbating adverse effects of Mn toxicity and in fact it was low light that accelerated the expression of toxic symptoms of Mn. It seems that the negative impacts of Mn toxicity are alleviated or accentuated by different light levels, depending on plant variation and tolerance.

2.4. Nickel (Ni). Ni is a micronutrient that is required by both higher and lower plants in very small amounts [83] but its phytotoxicity is deemed to be more important than its shortage [84]. Ni has various oxidative states but its divalent state $\left(\mathrm{Ni}^{2+}\right)$ is the most stable type in the environment and biological systems [85]. Although the role of $\mathrm{Ni}$ in metabolic processes of plants has not been identified as extensively as other elements such as $\mathrm{Mn}$ or $\mathrm{Cu}$, it is a key factor in the activation of enzyme urease, which is needed for nitrogen metabolism [86]. Moreover, it plays a part in seed germination and iron uptake [85]. The concentration level representing nickel toxicity in plants varies greatly from 25 to $246 \mu \mathrm{g} \cdot \mathrm{g}^{-1} \mathrm{dry}$ weight (DW) of plant tissue, depending on the plant species and cultivars [87]. Ni at excess competes with several cations, in particular, $\mathrm{Fe}^{2+}$ and $\mathrm{Zn}^{2+}$, preventing them from being absorbed by plants, which ultimately causes deficiency of $\mathrm{Fe}$ or $\mathrm{Zn}$ and results in chlorosis expression in plants [88].

Excess nickel adversely affects germination process and seedling growth traits of plants by hampering the activity of the enzymes such as amylase and protease as well as disrupting the hydrolyzation of food storage in germinating seeds $[89,90]$. Plant growth parameters and attributes are also affected by Ni toxicity. M. R. Khan and M. M. Khan [88] investigating the toxic effect of nickel and cobalt on chickpea (Cicer arietinum L.) showed that toxicity of $\mathrm{Ni}$ on the biomass production was more pronounced than Co and both metals led to poor nodulation, resulting in the reduced yield. AlQurainy [91] also demonstrated that $\mathrm{Ni}$ at the concentration $150 \mu \mathrm{g} \cdot \mathrm{g}^{-1}$ of soil severely reduced plant height and leaf area in bean.

$\mathrm{Ni}$, especially at high concentrations, can readily move through phloem and xylem vessels, thereby translocating smoothly from the root to the upper parts of plants [92]. This ease of movement towards shoots is due to the pattern by which $\mathrm{Ni}$ is distributed within the tissue of roots, which differs from some other HMs such as $\mathrm{Pb}$ and $\mathrm{Cd}$ so that it can pass through the endodermal barrier and amass in the pericycle cells [93]. Several studies in plants including maize [94] and cowpea [95] have confirmed this phenomenon and indicated that Ni toxicity can result in inhibited lateral root formation and development. Moreover, the agglomeration of $\mathrm{Ni}$ in root apex greatly hampers mitotic cell division in this organ, which ultimately results in growth reduction [96]. The induction of ROS, due to $\mathrm{Ni}$ toxicity, is observed in both agronomic and nonagronomic plants such as Jatropha curcas L. [97], or wheat [98], which results in a wide range of physiological and biological disorders including the impairment of cell membrane and enzymatic imbalance.

The adverse impact of toxic levels of $\mathrm{Ni}$ on the photosynthetic apparatus and performance is conspicuous. Sreekanth et al. [99] reported that $\mathrm{Ni}$ toxicity can lead to reduced Chl content and interruption of electron transport. Ghasemi et al. [100] in maize (Zea mays L.) showed that excess $\mathrm{Ni}$ perniciously influenced photosynthetic protein complexes and the rate of Hill reaction dwindled by increasing $\mathrm{Ni}$ concentration.

2.5. Copper $(\mathrm{Cu}) . \mathrm{Cu}$ is an essential micronutrient that participates in many vital physiological functions of plants including acting as a catalyzer of redox reaction in mitochondria, chloroplasts, and cytoplasm of cells [101] or as an electron carrier during plant respiration [102]. However, $\mathrm{Cu}$ becomes toxic when its concentration in the tissue of plants rises above optimal levels [103]. Cu exists in many states in soils but is mainly taken up by plants in the form of $\mathrm{Cu}^{2+}$ [104]. The concentration of copper in soil is typically between 2 and $250 \mu \mathrm{g} \cdot \mathrm{g}^{-1}$ and healthy plants can absorb $20-30 \mu \mathrm{g} \cdot \mathrm{g}^{-1}$ DW [105]. But copper availability depends greatly on soil $\mathrm{pH}$ and its phytoavailability increases with declining $\mathrm{pH}$ [106]. In addition, uptake of $\mathrm{Cu}$ by plants and its toxicity are contingent on nutritional condition of plant, $\mathrm{Cu}^{2+}$ concentration in soil, length of exposure, and genotype of a species [107]. A plethora of research studies such as [106] in Rhodes grass (Chloris gayana Knuth), [108] in clove (Syzygium aromaticum L.), [109] in cucumber (Cucumis sativus), and [110] in some 
Eucalyptus species indicate that copper has a propensity for the accumulation in the root tissues with little upward movement towards shoots. Therefore, the initial characterization of $\mathrm{Cu}$ toxicity is the hindrance of root elongation and growth [111]. The subsequent symptoms include chlorosis, necrosis, and leaf discoloration [102]. Excess $\mathrm{Cu}$ can become attached to the sulfhydryl groups of cell membrane or induce lipid peroxidation, which results in the damaged membrane and the production of free radicals in different plant organelles and parts [112]. Of these pernicious effects, damage to the permeability of root cells [113] and structural disturbance of thylakoid membranes [114] can be mentioned. $\mathrm{Cu}$ at toxic levels through redox process cycling between $\mathrm{Cu}^{+}$ and $\mathrm{Cu}^{2+}$ triggers the formation of reactive oxygen species such as singlet oxygen $\left(\mathrm{O}_{2}{ }^{-}\right)$and hydroxyl radical ( $\left.\mathrm{HO}^{*}\right)$, leading to injuries to macromolecules, for example, DNA, RNA, lipids, carbohydrates, and proteins $[103,115]$. Decreased photosynthetic competence, low quantum efficiency of PSII, and reduced cell elongation are also associated with $\mathrm{Cu}$ toxicity [109]. These trends have been observed in various levels of copper applied to different plants. In an in vivo study of bean (Phaseolus vulgaris L. cv. Dufrix), it was shown that toxic concentration of $\mathrm{Cu}(15 \mu \mathrm{M})$ depleted PSII action centers and led to photoinhibition and disruption of its repair cycle [116]. Moreover, the results obtained with rapeseed (Brassica napus L.) indicated that content of chlorophylls (Chl $a$ and $\mathrm{Chl} b$ ) as well as carotenoids was markedly dropped when this plant was exposed to $6 \mu \mathrm{mol} \cdot \mathrm{dm}^{-3}$ concentration of $\mathrm{Cu}$ [117]. Seedling growth characteristics are shown to be adversely affected by $\mathrm{Cu}$ toxicity. Sharma et al. [118] working with spinach seeds (Spinacia oleracea L.) found a significant negative correlation between the root and shoot elongation with increasing $\mathrm{Cu}$ levels, which was associated with a noticeable depression in seedling fresh weight. Mediouni et al. [119] comparing effects of cadmium and copper toxicity on tomato seedling (Lycopersicon esculentum Ibiza F1) observed that $\mathrm{Cu}$ and $\mathrm{Cd}$ significantly decreased biomass production of tomato. Also, $\mathrm{Cu}$ toxicity was found to be more pronounced and resulted in more induction of lipid peroxidation in the young seedlings, especially at high concentrations, than that of Cd.

2.6. Zinc (Zn). $\mathrm{Zn}$ is an essential trace metal that despite having no redox activity is particularly involved in many vital physiological events in plants [120]. Zinc is an indispensable component of special proteins known as zinc fingers that bind to DNA and RNA and contribute to their regulation and stabilization [121]. Moreover, it is a constituent of various enzymes, for example, oxidoreductases, transferases, and hydrolases [114], as well as ribosome [122], and plays a role in the formation of carbohydrates and chlorophyll and root growth [123].

Zinc, in divalent state $\left(\mathrm{Zn}^{2+}\right)$, is the most pervasive form found in soil and acquired by plants [124]. Zn bioavailability/phytoavailability is dependent on various variables including the total $\mathrm{Zn}$ concentration in soil, lime content and organic matter of soil, clay type, and presence of other HMs, soil's $\mathrm{pH}$, and the amount of salt in the substrate $[125,126]$.
Of these, $\mathrm{pH}$ is the most important factor influencing $\mathrm{Zn}$ availability [124] and higher $\mathrm{pH}$ is generally associated with the decreased absorption of $\mathrm{Zn}$ by plants [126]. $\mathrm{Zn}$ at high soil concentrations (150 to $300 \mu \mathrm{g} \cdot \mathrm{g}^{-1}$ ) is strongly toxic [127] and its phototoxicity, in addition to the bioavailability factors, depends on plant type and plant development stage [128]. Visual signs of trouble in plants as a result of $\mathrm{Zn}$ toxicity are reported to be chlorosis in young leaves due to iron or manganese deficiency [129] and appearance of purplish-red color in leaves due to phosphorus deficiency [127], which indicate that $\mathrm{Zn}^{2+}$ in excess can easily supersede other metals, especially those with similar ionic radii in the active sites of enzymes or transporters [130]. Moreover, necrotic spotting between the veins in the blade of mature leaves [131] and inward rolling at leaf margins [120] are attributed to $\mathrm{Zn}$ toxicity.

Excess $\mathrm{Zn}^{2+}$ in cells can produce ROS and adversely influence integration and permeability of membrane [132, 133]. Zn toxicity, akin to other HMs, hampers the functionality and efficiency of photosynthetic system in different plant species. Vassilev et al. [134] in bean plants, Mirshekali et al. [135] in sorghum (Sorghum bicolor L.), and lalelou et al. [136] in naked pumpkin (Cucurbita pepo) showed that excessive concentration of $\mathrm{Zn}^{2+}$ reduced the content of accessory photosynthetic pigments including $\mathrm{Chl} a$ and $\mathrm{Chl}$ $b$ by disturbing the absorption and translocation of $\mathrm{Fe}$ and $\mathrm{Mg}$ into chloroplast. The elevated level of $\mathrm{Zn}^{2+}$ is reported to cause a decline in initial and maximum $\mathrm{Chl}$ fluorescence, resulting in the repression of PSII activity [137]. Zinc in excess is found to have genotoxic effects on plants, resulting in genetic-related disorders and damages to plants. Oladele et al. [138] demonstrated that high levels of $\mathrm{Zn}\left(100 \mathrm{mg} \cdot \mathrm{L}^{-1}\right)$ in cells resulted in abnormal chromosomes, which was followed by a sticky metaphase and premature separation of chromosomes in bambara groundnut (Vigna subterranean). Also, Truta et al. [139] observed that the rate of ana-telophase aberrations was 2-3 times higher than control treatment when barely seedlings (Hordeum vulgare L.) were treated with 250 to $500 \mu \mathrm{M} \mathrm{Zn}^{2+}$.

Growth parameters and structure of plant parts are shown to be negatively affected by $\mathrm{Zn}$ toxicity. Todeschini et al. [140] demonstrated that $\mathrm{Zn}$ in poplar (Populus alba) drastically changed leaf morphology and ultrastructure and caused the formation of calcium-oxalate crystals. Vijayarengan and Mahalakshmi [141] showed that $\mathrm{Zn}$ toxicity decreased the length of root and shoot as well as area of leaves in tomato (Solanum lycopersicum L.).

\section{Some Defense Mechanisms Employed by Plants against HM Stress}

As mentioned earlier, plants possess a sophisticated and interrelated network of defense strategies to avoid or tolerate HM intoxication. Physical barriers are the first line of defense in plants against metals. Some morphological structures like thick cuticle, biologically active tissues like trichomes, and cell walls as well as mycorrhizal symbiosis 
can act as barriers when plants are faced with HM stress [12, 142, 143]. Trichomes, for instance, can either serve as HM storage site for detoxification purposes or secrete various secondary metabolites to negate hazardous effects of metals $[144,145]$. On the other hand, once HMs overcome biophysical barriers and metal ions enter tissues and cells, plants initiate several cellular defense mechanisms to nullify and attenuate the adverse effects of HMs. Biosynthesis of diverse cellular biomolecules is the primary way to tolerate or neutralize metal toxicity. This includes the induction of a myriad of low-molecular weight protein metallochaperones or chelators such as nicotianamine, putrescine, spermine, mugineic acids, organic acids, glutathione, phytochelatins, and metallothioneins or cellular exudates such as flavonoid and phenolic compounds, protons, heat shock proteins, and specific amino acids, such as proline and histidine, and hormones such as salicylic acid, jasmonic acid, and ethylene $[19,20,146]$. When the above-mentioned strategies are not able to restrain metal poisoning, equilibrium of cellular redox systems in plants is upset, leading to the increased induction of ROS [147]. To mitigate the harmful effects of free radicals, plant cells have developed antioxidant defense mechanism which is composed of enzymatic antioxidants like superoxide dismutase (SOD), catalase, (CAT), ascorbate peroxidase (APX), guaiacol peroxidase (GPX), and glutathione reductase (GR) and nonenzymatic antioxidants like ascorbate (AsA), glutathione (GSH), carotenoids, alkaloids, tocopherols, proline, and phenolic compounds (flavonoids, tannins, and lignin) that act as the scavengers of free radicals $[18,148,149]$. As previously indicated, some of the biological molecules involved in cellular metal detoxification can be multifunctional and have antiradical, chelating, or antioxidant activities. Exploitation and upregulation of any of these mechanisms and biomolecules may depend on plant species, the level of their metal tolerance [150], plant growth stage, and metal type. Some of the defense mechanisms used by plants against HMs will be discussed below.

3.1. Phytochelatins (PCs). One of the mechanisms adopted by plants to detoxify HMs is the production of shortchain thiol-rich repetitions of peptides of low-molecular weight synthesized from sulfur-rich glutathione (GSH) by the enzyme phytochelatin synthase (PCS) with the general structure of ( $\gamma$-glutamyl-cysteinyl) $n$-glycine $(n=2$ to 11) that have a high affinity to bind to HMs when they are at toxic levels [151-155]. Phytochelatins, as a pathway for metal homeostasis and detoxification, have been identified in a wide range of living organisms from yeast and fungi to many different species of animals $[156,157]$. In plants, PCs are found to be part of the defensive act not only against metal-related stresses but also in response to other stressors such as excess heat, salt, UV-B, and herbicide [158]. PCs are reported to be used as biomarkers for the early detection of HM stress in plants [159]. Cytosol is the place where PCs are manufactured and actively shipped from there in the form of metalphytochelatin complexes of high molecular weight to vacuole as their final destination $[24,160]$. It has been suggested that the transport is mediated by $\mathrm{Mg}$ ATP-dependent carrier or ATP-binding cassette (ABC) transporter [15].
The precipitous induction of PCs occurs inside cells as result of the varying levels of multiple types of HMs where PCs via sulfhydryl and carboxyl groups can attach to some $\mathrm{HM}$ cations and anions such as $\mathrm{Cd}, \mathrm{Cu}, \mathrm{Ag}, \mathrm{Zn}, \mathrm{Pb}, \mathrm{Ni}$, and Ar $[155,161,162]$. However, $\mathrm{Cd}^{2+}$ ions are found to be the most effective stimulator of PCs synthesis where they are 4to 6-fold stronger in inducing PCs than $\mathrm{Cu}^{2+}$ and $\mathrm{Zn}^{2+}$ in cell cultures of Rauvolfia serpentina [163] and red spruce (Picea rubens Sarg), respectively [164]. PCs can be both produced and accumulated in roots and aerial organs. Nevertheless, the majority of studies suggest that they tend to be first biosynthesized and amass in roots. It has been shown that, in sunflower exposed to Cd intoxication, phytochelatins levels in roots were at least two times as much as those in leaves [165].

Fidalgo et al. [166] in Solanum nigrum L. showed that the production of PCs was enhanced in roots when the plant was exposed to $200 \mu \mathrm{mol} \cdot \mathrm{L}^{-1} \mathrm{Cu}$, which resulted in the immobilization of $\mathrm{Cu}$ excess in the root and its preclusion from moving toward the shoot. Batista et al. [167] concluded that the stimulation of different As-PC complexes in roots of some rice cultivars subjected to the elevated levels of arsenic reduced the transport of As from soil or root to the aerial parts and grains. These strategies can be effective in terms of preventing toxic metals from reaching the consumable parts of crops. On the other hand, some investigations show that when time variable is factored into the experiment and plants are exposed to the protracted HM stress, PCs-related activities as well as their concentration are increased in leaves. Heiss et al. [168] demonstrated that prolonged exposure of Brassica juncea to Cd resulted in 3-fold higher accumulation of PCs in leaves than roots. Szalai et al. [169] observed that treating maize plants with $\mathrm{Cd}$ for a longer period of time led to decreased PCs action in roots and increased level of phytochelatin synthase in leaves. They suggested that feedback regulation process or substrate reduction may be accountable for this phenomenon. In addition to the aforementioned factors, it seems that the type of plants in terms of their degree of tolerance to HM excess plays a role in determining PCs production, accumulation, and transportation site as well as their preferred movement path in plants. Zhang et al. [170] suggested that principal Cd detoxification mechanism in hyperaccumulator Sedum alfredii mediated by PCs occurs in shoots, which is similar to nonresistant plants. However, this event for wheat plant, as an efficient Cd accumulator, happened in roots [171]. In hyperaccumulators, it appears that they adopt mechanisms that involve long-distance translocation of PCs from root to shoot [172].

PCs chain lengths show variation within and among plant species as well as with HM types. Brunetti et al. [173] reported that $\mathrm{PC}_{4}$ was most pervasive oligomer in tobacco seedlings (Nicotiana tabacum L.) whereas $\mathrm{PC}_{3}$ was of higher concentration in Arabidopsis. In legumes, it is reported that $\mathrm{PCs}$ with longer chains are stronger binder to $\mathrm{Pb}$ in comparison to shorter PCs [174]. But there is no conclusive study to show whether the number of chains can have any impacts on the effectiveness of the PCs. Phytochelatins 
along with antioxidative enzymes can form a synergistic defensive regime in plants under HM stress which, in turn, can strengthen plant's resistance against metal intoxication. Chen et al. [152] demonstrated that the increased enzymatic biosynthesis of PCs coupled with the heightened activity of antioxidative system in Brassica chinensis L. led to an effective detoxification of $\mathrm{Cd}$. A considerable effort has been made to identify and clone PCS genes that are responsible for the production of PCs. Arabidopsis thaliana phytochelatin synthase (AtPCS1) and wheat (Triticum aestivum L.) phytochelatin synthase (TaPCS1) were amongst the first plant PCS genes that were extracted [162]. The ongoing investigation into this area has led to the identification of various PCS genes in distinct plant species such as Brassica juncea (BjPCS1) and rice (Oryza sativa L.) (OsPCS1) $[168,175]$.

Real or synthetic expression of these genes in PCdeficient and transgenic plants or hyperaccumulators offer a very promising future for the possibility of increasing plants resistance against HMs and also phytoremediation strategies. In transgenic tobacco plants, artificial synthesis of phytochelatin gene enhanced their resistance to varying levels of cadmium [176]. Shukla et al. [154] showed transgenic Arabidopsis plants were much better HM accumulators than wild type Arabidopsis as a result of expressing synthetic phytochelatins (ECs). Guo et al. [177] demonstrated that overexpression of arsenic-phytochelatin synthase 1 (AsPCS1) and yeast cadmium factor 1 (YCF1) (isolated from garlic and baking yeast) in Arabidopsis thaliana resulted in an increased tolerance to $\mathrm{Cd}$ and $\mathrm{As}$ and also enhanced its ability to accumulate the metals to a greater extent.

3.2. Metallothioneins (MTs). MTs, which were first extracted from equine kidney in 1957 [178], are another family of small cysteine-rich, low-molecular-weight cytoplasmic metal-binding proteins or polypeptides that are found in a wide variety of eukaryotic organisms including fungi, invertebrates, mammals, and plants as well as some prokaryotes [179-181]. Contrary to PCs that are the product of enzymatically synthesized peptides, MTs are synthesized as a result of mRNA translation [182]. Whereas PCs in plants may mainly deal with Cd detoxification, MTs appear to be capable of showing affinity with a greater range of metals such as $\mathrm{Cu}, \mathrm{Zn}, \mathrm{Cd}$, and As [183]. MTs exhibit different characteristics and functionality based on their occurrence in different organisms; however, as our understanding towards the roles of plant MTs increases and given the fact that plant MTs are exceedingly varied in terms of their molecular properties and structural features [184], they are likely to have more and diverse functions in plant than any other living organisms. In plants, these ligands are involved in nullifying toxicity of HMs through cellular sequestration, homeostasis of intracellular metal ions, and metal transport adjustment $[21,185,186]$. In addition to their role in HM detoxification, MTs are known to be active agents in a number of cellularrelated events including ROS scavenger [142], maintenance of the redox level [180], repair of plasma membrane [187], cell proliferation, and its growth and repair of damaged DNA [188]. There are a myriad of different endogenous and exogenous factors other than HMs that are able to induce the production and expression of MTs. Of these, osmotic stress, drought, extreme temperatures, nutrient deficiency, release of various hormones, natural and dark-induced tissue senescence, injuries, and viral infections can be mentioned $[24,179,183]$.

Plants have multiple MT types that are generally divided into four distinct subgroups according to the arrangement of Cys residues [189]. They demonstrate patterns of organ and developmental stage specificity so that type 1 MTs are mainly expressed in roots, while the expression of type 2 MTs mostly occurs in shoots, type 3 MTs are induced in leaves and during fruit ripening, and type 4 MTs are abundant in the developing seeds $[183,186]$. Regarding high level of sequence diversity of plant MT [190], each MT subgroup (MT1 to MT4) is further subdivided and referred to as isoforms. Guo et al. [185] subdivided sugarcane MT2 into three subclasses and termed them as MT2-1, MT2-2, and MT2-3 or in Arabidopsis MT4 are subdivided into MT4a and MT4b [21]. It seems that all four types of MTs and their isoforms identified in plants are able to bind to HMs and act as metal chelators or storehouse; however, mounting evidence suggests that on the one hand plant MTs show distinct treatment towards varying types of metals and on the other hand functionality of these plant MTs and their metal-binding and metal-affinity characteristics as well as tissue localization might be different within a plant species or among species.

Grennan [188] reported that, in Arabidopsis, there is every likelihood that MT isoforms from types 1 and 2 (1a, $2 \mathrm{a}$, and $2 \mathrm{~b}$ ) and 3 are involved in copper chelation, while MTs isoforms from type 4 ( $4 \mathrm{a}$ and $4 \mathrm{~b}$ ) act as a zinc binder. García-Hernández et al. [191] showed that, in some mutants of Arabidopsis, MT1 may play a more important role in detoxifying copper in leaf veins than in leaf mesophyll. Yang et al. [192] showed that the induction of OsMT1a (Oryza sativa L. metallothionein type 1) was crucial to the zinc homeostasis in roots of rice. In grain-filling and mature seeds of barely, it was demonstrated that the primary function of MT3 is to maintain homeostasis of $\mathrm{Zn}$ and $\mathrm{Cu}$, whereas MT4 was involved in storage of $\mathrm{Zn}$ [193]. In soybean, it was shown that MT1, MT2, and MT3 were more likely to get involved in detoxification of deleterious amounts of Cd, whilst MT4 exhibited Zn-binding characteristics [194]. It can be suggested that varying types of MTs and their isoforms have distinct and overlapping functions in homeostasis and HM detoxification [179]. More work still needs to be done to find out the possible reasons for these differential and preferential behavior of plant MTs towards metals; nevertheless, it appears that differences in genetic structure of plants, complex diversity in the metal binding regions of plant MTs [188], and different sequence and performance of isoforms [195] might be able to provide some explanation to the observed patterns. Overexpression experiments are very popular with plant MTs and expressing as well as engineering them through DNA recombinant methods into plants, yeasts, and bacteria that lack some of these proteins can increase our knowledge of MTs and their performance to a greater extent and also provide unique opportunities for phytoremediation or bioremediation strategies. Some works are suggestive of 
MTs promoting the capability of transgenic plants in terms of decreasing the production of reactive oxygen species and fortifying cellular antioxidant defense system when it comes to detoxifying excessive levels of HMs. Xia et al. [196] showed that expression of Elsholtzia haichowensis metallothionein type 1 (EhMT1) in tobacco plants not only increased the tolerance of transgenic tobacco to copper toxicity but also decreased the synthesis of hydrogen peroxide and improved peroxidase activity (POD) in roots, leading to enhanced ability of plants to cope with oxidative stress. Zhou et al. [9] demonstrated that although TaMT3, a metallothionein type 3 from Tamarix androssowii, engineered into tobacco resulted in increased tolerance to $\mathrm{Cd}$ stress through significant increases of SOD functionality, which raised the ability of ROS cleaning-up in transgenic plant, it led to decreased POD activity. It seems that the impact of the expressed metallothionein on distinct components of antioxidant system of transgenic plants is different, which requires further investigation. Ectopically expressed MTs in transgenic plants are shown to enhance their tolerance towards metal intoxication. Kumar et al. [197] showed that OSMT1e-p, a type 1 MT obtained from a salt tolerant rice genotype (Oryza sativa L. cv. Pokkali), imparted tolerance towards copper and zinc toxicity when ectopically expressed in transgenic tobacco. They observed that tobacco plants that had received the gene tended to retain excessive amounts of $\mathrm{Cu}^{2+}$ and $\mathrm{Zn}^{+2}$ in their roots or lower leaves, significantly reducing the HMs ions movement and content to/in upper foliage and harvestable organs. Zhigang et al. [198] concluded that the ectopic expression of BjMT2, a metallothionein type 2 from Brassica juncea, in Arabidopsis thaliana increased copper and cadmium tolerance at the seedling stage but acutely reduced root development when there was no heavy metal exposure. These trends may suggest that ectopic expression of MTs in transgenic plants may act in host plant in a nonspecific way and differently impact the organ growth.

3.3. Proline (Pro). Pro is a proteinogenic five-carbon $\alpha$-amino acid that acts as a compatible and metabolic osmolyte, a constituent of cell wall, free radical scavenger, antioxidant, and macromolecules stabilizer [94, 199, 200]. Some other functions of Pro include promoting embryo/seed evolvement, extending stem length as well as moving plants from vegetative growth to reproductive stage [201]. The production of elevated levels of Pro by higher plants is a typical nonenzymatic response to tensions caused by a wide range of biotic and abiotic stressors such as excessive salinity, drought, increased solar ultraviolet (UV) radiation, HMs, and oxidative stress [202]. In fact, Pro plays multifarious roles including adaptation, recovery, and signaling when it comes to combating stress in plant [166]. A number of mechanisms by which Pro increases the resistance of plants to HM toxicity have been proposed.

Clemens [203] suggested that HM-induced Pro accumulation in plants is not directly emanated from HM stress, but water balance disorder, which occurs as a result of metal excess, is responsible for the induction of Pro. In this regard, Pro functions as an osmoregulator or osmoprotectant. Mourato et al. [147] and Tripathi and Gaur [204] proposed that ROS scavenging by Pro, which is stimulated by HM stress, is primarily conducted through detoxifying hydroxyl radicals and quenching singlet oxygen. Increase in antioxidant enzyme activities, their protection, maintenance of cellular redox homeostasis [147], and reconstruction of Chl as well as regulation of intracellular $\mathrm{pH}$ [149] are associated with the activity of Pro when plants are exposed to HMs. It is reported that Pro can act as a metal chelator and protein stabilizer [187]. However, Tripathi and Gaur [204] in Scenedesmus sp. surveying the relationship between zinc and copper-induced stress and Pro accumulation did not support the notion that Pro functions as a metal chelator.

Literature review shows that the induction of Pro in plants in response to $\mathrm{HM}$ is to a great extent concentrationdependent, organ and metal specific. In hyperaccumulator Cynara scolymus L. (artichoke), it is demonstrated that there is a linear association between Pro augmentation in cells and HM concentration [205]. Gohari et al. [206] showed that Pro concentration in root of rape seed (Brassica napus L.) increased when the plant was exposed to rising concentrations of $\mathrm{Pb}^{2+}(100$ to $400 \mu \mathrm{M})$ but Pro accumulation at aerial parts was not as conspicuous as root. The same organspecific accumulation of proline where roots contained more proline than shoots is exhibited in a plethora of experiments with different plants including Brassica juncea L. subjected to $\mathrm{Pb}$ and $\mathrm{Cd}$ stress [23], Solanum nigrum L. exposed to $\mathrm{Cu}$ stress [166], wheat subjected to Cd [207], and lemongrass (Cymbopogon flexuosus Stapf) subjected to $\mathrm{Hg}$ and Cd stress [208]. In hybrid poplar (Populus trichocarpa $\times$ deltoides), it was shown that Pro accumulation in roots was almost 2 -fold higher than that of leaves when Cd was applied in strong doses, but there was no significant difference between leave and root Pro content at lower concentrations of the metal [209]. However, contrary to the above-mentioned works, some reports indicate that Pro tends to more accumulate in shoots of HM-stressed plants than in roots $[146,210]$. It seems that, in addition to type of plant species and preferential accumulation of metals within plant parts, condition and variables of experiments, such as heavy metal concentration, temperature, and duration of exposure as well as substances supplemented to experimental medium are crucial factors determining the way Pro augmented in plant parts. However, the rapid induction of Pro in roots and forming Pro-metal complexes may offer a better and effective way of nullifying toxicity of metals rather than allowing them to reach aboveground parts. Theriappan et al. [211] experimenting with cauliflower seedlings (Brassica oleracea var. botrytis) and three HMs (Cd, Hg, and $\mathrm{Zn}$ ) noticed the concentrationdependent accumulation of Pro in which intensification of toxicity (up to $1000 \mu \mathrm{M}$ ) almost doubled the production of Pro. Additionally, they showed that $\mathrm{Hg}$ was the strongest initiator of Pro. In another study using sal seedling (Shorea robusta), it was determined that $\mathrm{Cd}, \mathrm{Pb}$, and As were, respectively, stronger evokers of proline [212]. Kumar et al. [213] in wheat seedlings found that $\mathrm{Cu}$ was stronger inducer of Pro than Zn. Rastgoo et al. [149] studying effects of 
equimolar amounts ( $50 \mu \mathrm{M}$ and $100 \mu \mathrm{M}$ ) of $\mathrm{HMs}$ (Cd, $\mathrm{Co}, \mathrm{Pb}$, and $\mathrm{Ag}$ ) on Gouan (Aeluropus littoralis) found that maximum Pro accumulation occurred when the plant was treated with Cd. Zengin and Kirbag [210] showed that Pro content in sunflower seedlings subjected to various amounts of HMs was strongly induced in the order of $\mathrm{Hg}>\mathrm{Cd}>\mathrm{Cu}>\mathrm{Pb}$. The results obtained from these studies indicate that the capability of a specific trace metal to induce proline accumulation may depend on the concentration and specificity of HMs, their toxicity threshold, and plant species employed in the trials. As indicated by Ruscitti et al. [214] increasing HM concentration raises the content of cell Pro to a specific level, after which suppression of Pro accumulation occurs as the amount of metal increases beyond a certain threshold.

Spraying Pro on the foliar parts of plants grown under HM stress is shown to be an effective method to reduce the poisonousness of metals and give rise to the activation of protective mechanisms in plants in order to negate toxic effects of HMs. Hayat et al. [215] showed that exogenously applied Pro on cadmium stressed-chickpea enhanced the activity of antioxidative enzymes, carbonic anhydrase and photosynthetic parameters, which all contributed to the increased tolerance of the plant to $\mathrm{Cd}$. Moreover, they observed that there was a sharp rise in the content of endogenously produced Pro when the plant received Pro from exogenous sources, thereby aiding it to better cope with the metal stress. Shahid et al. [216] showed that the exogenous application of Pro (pure synthetic proline or proline fortified with essential nutrients) on pea protected the plant against phytotoxic impacts of nickel by reducing lipid peroxidation and electrolyte leakage, heightening activities of polyamine biosynthetic enzymes and improving leaf polyamines and increasing concentration of endogenous compatible solutes. It was also concluded that Pro enriched with nutrients was more effective than pure Pro in enhancing plant growth under stress. Hayat et al. [217] reported that exogenous Pro can form complex with various metals such as $\mathrm{Cu}$, $\mathrm{Cd}$, and $\mathrm{Zn}$ in which it can overcome inhibition of nitrate reductase caused by metal toxicity. It is reported that Pro pretreatment can ameliorate the phytotoxicity of $\mathrm{Hg}^{+2}$ in rice by reducing ROS concentration [218]. Role of exogenous Pro in HM detoxification especially testing different enriched extracts containing Pro needs to be paid more attention. Furthermore, priming seeds with Pro for the purpose of increasing the tolerance of plants to HM toxicity has the merit of investigation.

3.4. Arbuscular Mycorrhizal (AM). Symbiotic mycorrhizal fungi such as AM form a mutualistic symbiosis with roots of most vascular plant species under different climatic conditions in which they are beneficiary of photosynthetic assimilations provided by plants and in return they improve the mineral nutrition status of plants and can also enhance their tolerance towards some stresses and pollutants [219221]. Plant-fungal mutualism may act as a precursor in which it signals the herald of stress to symbiotic plants so that they can make their protective mechanisms active to ameliorate deleterious effects of stress earlier than nonsymbiotic plants
[214]. Although most of the discussions involving mycorrhizal symbiosis with plant roots in relation to HMs fall under the category of bioremediation methods, its multifarious and crucial services to plants make it inevitable to view this relationship from the protective aspects, which contributes to overall defensive systems of plants, in particular, against external stressors, like HMs. Principal mechanisms adopted by mycorrhizal fungi to cancel out impacts of HM stress on plants include acting as a barrier by depositing metals within cortical cells [222], binding metals to cell wall or mycelium as well as sequestering them in their vacuole or other organelles [12] releasing heat-shock protein and glutathione [223], precipitating or chelating metals in the soil matrix via producing glycoprotein or making phosphatemetal complexes inside the hyphae [224-226], and reducing the strength of metals by heightened root and shoot growth [227]. The varied strategies employed by AM when facing toxicity of HMs suggest that different species of mycorrhizal fungi might act specifically or adopt the remedial function which suits the prevailing condition in either rhizosphere or plant.

It was shown that in ryegrass (Lolium perenne L.), which has a symbiotic relationship with AM, the translocation of $\mathrm{Cd}, \mathrm{Ni}$, and $\mathrm{Zn}$ from soil to different parts of the plant was significantly reduced as a result of immobilization of HMs in soil [228]. The same result was obtained by Shivakumar et al. [229] when working with green gram (Vigna radiata) grown in soil containing excessive $\mathrm{Zn}$. It is reported that the changes in $\mathrm{pH}$ soil due to the activities of $\mathrm{AM}$ fungi are a major contributing factor to the immobilization of metals in mycorrhizosphere region [230]. Huang et al. [231] showed that AM fungus (Glomus mosseae) decreased availability of excessive $\mathrm{Zn}, \mathrm{Cu}$, and $\mathrm{Pb}$ for maize growing in HM contaminated soil through binding the metals to organic matters or absorbing them into its organs, thereby limiting the possibility of metal uptake by host plant. When antioxidant defense machinery of plants exposed to elevated levels of HMs is exhausted as a result of induction of reactive oxygen species, AM association can reduce or prevent the induction of ROS species and also give a boost to the activity of detoxifying enzymes within plants. Abad and Khara [232] showed that wheat plants colonized by different AM fungi species subjected to toxic levels of Cd had conspicuously more functionality of protective antioxidants such as APX and GPX in their roots and shoots compared to nonAM wheat. They also observed that, among fungal species, Glomus veruciforme and Glomus etunicatum were the most effective activators of the protective proteins. The decrease in lipid peroxidation and electrolyte leakage and increased activities of superoxide dismutase (SOD), catalase (CAT), and peroxidase (POX) are observed in mycorrhizal pigeon pea (Cajanus cajan L.) plants under $\mathrm{Cd}$ and $\mathrm{Pb}$-contaminated soils [233]. Farshian et al. [234] demonstrated that lettuce plants (Lactuca sativa L.) under $\mathrm{ZnSO}_{4}$ stress which were inoculated with AM fungus (Glomus etunicatum) had higher levels of cellular protein and, as a result, increased content of antioxidant enzymes compared to noninoculated ones, due to the fact that the AM fungus had sequestered $\mathrm{Zn}$ in its hyphae. However, chlorophyll and sugar content decreased 
in both AM and non-AM plants. In contrast, Rahmaty and Khara [235] observed that Cr-stressed maize plants treated with AM fungus (Glomus intraradices) had greater Chl content compared to maize plants that had not received AM treatment. It seems that metal or plant specificity is involved in this discrepancy of results. The information on the way by which AM fungi influence production and augmentation of other metabolites such as PCs, MTs, and Pro in heavy-metal stressed plants are rather scant and ambiguous. Abdelmoneim et al. [236] experimenting with $\mathrm{Cu}$ and Cd-stressed maize plants inoculated with two species of mycorrhizal fungi (Glomus mosseae and Acaulospora laevis) observed that there was a decline in Pro accumulation in AM infected maize compared to non-AM maize and the success of fungal and plant association in reducing deleterious effects of HM was attributed to other factors. However, Ruscitti et al. [214] showed that the interaction of mycorrhizal inoculation (Glomus mosseae and Glomus intraradices) and Cr-stressed pepper plants (Capsicum annuum L.) resulted in increased leaf Pro content but depressed root Pro concentration. Amanifar et al. [237] observed that shoot Pro concentration in mycorrhizal tomato (Lycopersicon esculentum L.) subjected to $\mathrm{Pb}$ treatment and inoculation of the above-mentioned Glomus species was not significantly affected when compared to control plants but there was a pronounced increase in root Pro content. They stated that observed different pattern of Pro induction in metal-stressed plants inoculated with AM may be due to fungal species, plant, and HM type. Moreover, it seems that growth condition, method of inoculation, and time of exposure to heavy metal intoxication may play a role in determining the way through which Pro is produced in the presence of AM. Further studies are needed to be done to determine the possible antagonistic or synergistic interaction between AM fungi and the protective metabolites which are copiously produced by metal-stressed plants. Major crops such as wheat, maize, and rice are exhibited to be the hosts of AM fungi [238], which necessitate the identification and propagation of proper fungus species that are efficient in increasing plant tolerance to HM toxicity.

\section{Conclusion and Future Outlook}

Contamination of soil and water by HMs in changing environment poses a serious threat to public and food safety and is now emerging as a major health hazard to humans and plants. This has become more accentuated and prominent as human-made disturbance of biological resources of the planet has accelerated the occurrence of many abiotic stresses for example, HMs. As a consequence, plants are now exposed to toxicity of HMs more than any time in their history since the beginning of their terrestrial life on planet earth. This necessitates making more efforts to deepen our appreciation of HMs and the way plants respond to their ever-growing presence. In current review, the various detrimental consequences of plant exposure to HM stress were discussed. This ranged from symptomatic and morphological manifestation of HM toxicity on the main organs of plants to inter- and intracellular intoxication.
This review showed that HMs, irrespective of their redoxassociated mode of action, are capable of disrupting prooxidants/antioxidants equilibrium in plant cells, tilting the balance in favor of the latter, inducing ROS, and directly reacting with functioning cellular macromolecules and organelles. Moreover, replacement of the essential cations with the toxic $\mathrm{HM}$ ions and their attachment to active groups of cofactors are common degenerative phenomena caused by HMs stress. This explains why there is a remarkable resemblance between the visual symptoms which occur in HM-stressed plants and the ones suffering from dearth of essential nutrients. It is evident that, in addition to plant type variation and HM threshold limit concentration, edaphic and light conditions are of key factors determining the occurrence, intensity, and toxicity of HMs. Also, uptake, mobility, and translocation of HMs within plant tissues or cells are greatly dependent on plant species, HM type, and concentration as well as oxidation state of HMs. We described some diverse defense procedures employed by plants when encountering deleterious impacts of HMs. All plant species, either tolerant or sensitive to HM stress, possess a basic defense system which gets activated upon the perception of threat from HMs. Commendable advances and progress achieved in molecular and biological fields have shed some light on the understanding of some complex strategies used by plants at cellular and molecular levels to combat metal stress. In this regard, functional diversity and molecular versatility of PCs and MTs are becoming intriguing when it comes to HM detoxification and maintaining cellular ion balance. Their role seems to go beyond being mere HM-chelating peptides or HM vacuolar and cellular sequestrators. They may act as cellular homeostatic or detoxifying agents. In particular, PCs and MTs are likely to interact directly or indirectly with plant antioxidant defense system or get involved in translocating and distributing excessive ion metals between root and shoot in a time or tissue-specific manner. Moreover, there are obvious indications that use of transgenic plants overexpressing PCs or MTs confers substantial HM tolerance. Therefore, transgenic and candidate gene approaches can be effectively adopted for phytoremediation purposes or for the fortification of plants that are deficient in PCs or MTs. This review also demonstrated that multifunctionality of Pro in aiding plants to tolerate HM stress is considerable since it can exhibit both chelating and antioxidant-related activities; however, its functions and effectiveness are immensely varied based on HM type and concentration and also according to plant variety as well as organ and tissue types. We explained that the contribution of AM symbiosis to plant defense system against HM stress is indispensable so that it may encompass or regulate many HM defense activities such as HM stress signaling, chelating, ion homeostasis control, and compatible solutes augmentation. Furthermore, AM and some antioxidant components such as SOD, APX, and CAT are likely to act in an integrated manner at excessive levels of HMs and raise plant tolerance to HM stress. However, although possible interrelatedness between AM and Pro is reported, a definite collaboration of AM with Pro may not yet be elucidated. 
Literature review indicates that there are some areas that are needed to be explored more thoroughly. Under the condition imposed by climate change, water from soil is depleted at faster rate than ever and intensity of some abiotic stresses is increased. Therefore, it is essential to examine the impacts of HM stress on plants by simultaneous application of several stress factors such as heat, drought, light, and salinity. In addition, the elevated levels of atmospheric trace gases and their possible links to HM stress should be investigated. This will also provide a comprehensive assessment of responses and evaluation of the effectiveness of transgenic plants to HMs under climate change circumstance. Since most of our information concerning plant defense mechanisms against heavy metal toxicity comes from adult plants, it is important to conduct more studies with young plants in order to compare and contrast between their defense system and adult plants against HM stress. The relationship between plant antioxidative defense mechanisms and HM chelators such as PCs or MTs ligands also needs to be well defined and established. This becomes more important as MTs exhibitantioxidant activities. There is no clear evidence how activities amongst these apparently separate defense systems are coordinated and whether they act synergistically or antagonistically in relation to antioxidative systems when plants are confronted with metal toxicity.

Exogenous application of various organic or inorganic compounds and their possible ameliorative effects on HMinduced toxicity in plants signify a promising future. In addition to Pro, it is shown that exogenously applied nitric acid (NO) and salicylic acid (SA) have protective effects against deleterious impacts of HMs [98, 239]. It is essential to improve our understanding of the exact mechanisms involved in the actions of such biological molecules and the level of their interaction with different plant species in alleviating adverse effects of HMs. There is a great need to find out how HMs affect crop plants in low input sustainable farming practices where there is a considerable emphasis in terms of supplying soil with organic fertilizers like compost with the objective of maintaining and boosting the association between naturally occurring or artificially introduced mycorrhiza and plants. Furthermore, examination and selection of suitable AM species for an efficient symbiotic relationship with plants towards combating HM stress are required to be done in an extensive manner.

\section{Conflict of Interests}

The authors declare that there is no conflict of interests regarding the publication of this paper.

\section{Acknowledgments}

The work was supported by the 12th Five-Year Forestry Science and Technology Support Program of China (no. 2012BAD23B05) and by the Priority Academic Program Development of Jiangsu Education Administration.

\section{References}

[1] P. C. Nagajyoti, K. D. Lee, and T. V. M. Sreekanth, "Heavy metals, occurrence and toxicity for plants: a review," Environmental Chemistry Letters, vol. 8, no. 3, pp. 199-216, 2010.

[2] H. Ali, E. Khan, and M. A. Sajad, "Phytoremediation of heavy metals-concepts and applications," Chemosphere, vol. 91, no. 7, pp. 869-881, 2013.

[3] S. J. S. Flora, M. Mittal, and A. Mehta, "Heavy metal induced oxidative stress \& its possible reversal by chelation therapy," Indian Journal of Medical Research, vol. 128, no. 4, pp. 501-523, 2008.

[4] A. Cirlaková, "Heavy metals in the vascular plants of Tatra mountains," Oecologia Montana, vol. 18, pp. 23-26, 2009.

[5] N. Rascio and F. Navari-Izzo, "Heavy metal hyperaccumulating plants: how and why do they do it? And what makes them so interesting?" Plant Science, vol. 180, no. 2, pp. 169-181, 2011.

[6] R. A. Wuana and F. E. Okieimen, "Heavy metals in contaminated soils: a review of sources, chemistry, risks and best available strategies for remediation," ISRN Ecology, vol. 2011, Article ID 402647, 20 pages, 2011.

[7] A. Schützendübel and A. Polle, "Plant responses to abiotic stresses: heavy metal-induced oxidative stress and protection by mycorrhization," The Journal of Experimental Botany, vol. 53, no. 372, pp. 1351-1365, 2002.

[8] B. V. Tangahu, S. R. S. Abdullah, H. Basri, M. Idris, N. Anuar, and M. Mukhlisin, "A review on heavy metals (As, $\mathrm{Pb}$, and $\mathrm{Hg}$ ) uptake by plants through phytoremediation," International Journal of Chemical Engineering, vol. 2011, Article ID 939161, 31 pages, 2011.

[9] B. Zhou, W. Yao, S. Wang, X. Wang, and T. Jiang, "The metallothionein gene, TaMT3, from Tamarix androssowii confers $\mathrm{Cd}^{2+}$ tolerance in Tobacco," International Journal of Molecular Sciences, vol. 15, no. 6, pp. 10398-10409, 2014.

[10] M. Patra, N. Bhowmik, B. Bandopadhyay, and A. Sharma, "Comparison of mercury, lead and arsenic with respect to genotoxic effects on plant systems and the development of genetic tolerance," Environmental and Experimental Botany, vol. 52, no. 3, pp. 199-223, 2004.

[11] F. K. Zengin and O. Munzuroglu, "Effects of some heavy metals on content of chlorophyll, proline and some antioxidant chemicals in bean (Phaseolus vulgaris L.) seedlings," Acta Biologica Cracoviensia Series Botanica, vol. 47, no. 2, pp. 157-164, 2005.

[12] J. L. Hall, "Cellular mechanisms for heavy metal detoxification and tolerance," Journal of Experimental Botany, vol. 53, no. 366, pp. 1-11, 2002.

[13] M. A. Hossain, P. Piyatida, J. A. T. da Silva, and M. Fujita, "Molecular mechanism of heavy metal toxicity and tolerance in plants: central role of glutathione in detoxification of reactive oxygen species and methylglyoxal and in heavy metal chelation," Journal of Botany, vol. 2012, Article ID 872875, 37 pages, 2012.

[14] M. Farid, M. B. Shakoor, A. Ehsan, S. Ali, M. Zubair, and M. S. Hanif, "Morphological, physiological and biochemical responses of different plant species to Cd stress," International Journal of Chemical and Biochemical Sciences, vol. 3, pp. 53-60, 2013.

[15] O. Sytar, A. Kumar, D. Latowski, P. Kuczynska, K. Strzałka, and M. N. V. Prasad, "Heavy metal-induced oxidative damage, defense reactions, and detoxification mechanisms in plants," Acta Physiologiae Plantarum, vol. 35, no. 4, pp. 985-999, 2013. 
[16] R. Rellán-Álvarez, C. Ortega-Villasante, A. Álvarez-Fernández, F. F. D. Campo, and L. E. Hernández, "Stress responses of Zea mays to cadmium and mercury," Plant and Soil, vol. 279, no. 1-2, pp. 41-50, 2006.

[17] M. M. Hatata and E. A. Abdel-Aal, "Oxidative stress and antioxidant defense mechanisms in response to cadmium treatments," American-Eurasian Journal of Agricultural \& Environmental Sciences, vol. 4, no. 6, pp. 655-669, 2008.

[18] P. Sharma, A. B. Jha, R. S. Dubey, and M. Pessarakli, "Reactive oxygen species, oxidative damage, and antioxidative defense mechanism in plants under stressful conditions," Journal of Botany, vol. 2012, Article ID 217037, 26 pages, 2012.

[19] K. Viehweger, "How plants cope with heavy metals," Botanical Studies, vol. 55, no. 35, pp. 1-12, 2014.

[20] A. A. Dalvi and S. A. Bhalerao, "Response of plants towards heavy metal toxicity: an overview of avoidance, tolerance and uptake mechanism," Annals of Plant Sciences, vol. 2, no. 9, pp. 362-368, 2013.

[21] A. R. Memon, D. Aktoprakligil, A. Zdemur, and A. Vertii, "Heavy metal accumulation and detoxification mechanisms in plants," Turkish Journal of Botany, vol. 25, no. 3, pp. 111-121, 2001.

[22] M. N. V. Prasad, "Phytoremediation of metals in the environment for sustainable development," Proceedings of the Indian National Science Academy, vol. 70, no. 1, pp. 71-98, 2004.

[23] R. John, P. Ahmad, K. Gadgil, and S. Sharma, "Heavy metal toxicity: effect on plant growth, biochemical parameters and metal accumulation by Brassica juncea L," International Journal of Plant Production, vol. 3, no. 3, pp. 65-76, 2009.

[24] A. Manara, "Plant responses to heavy metal toxicity", in Plants and Heavy Metals, A. Furini, Ed., SpringerBriefs in Molecular Science, pp. 27-53, Springer, Dordrecht, Netherlands, 2012.

[25] M. Valko, H. Morris, and M. T. D. Cronin, "Metals, toxicity and oxidative stress," Current Medicinal Chemistry, vol. 12, no. 10, pp. 1161-1208, 2005.

[26] M. Jozefczak, T. Remans, J. Vangronsveld, and A. Cuypers, "Glutathione is a key player in metal-induced oxidative stress defenses," International Journal of Molecular Sciences, vol. 13, no. 3, pp. 3145-3175, 2012.

[27] S. J. S. Flora, "Structural, chemical and biological aspects of antioxidants for strategies against metal and metalloid exposure," Oxidative Medicine and Cellular Longevity, vol. 2, no. 4, pp. 191-206, 2009.

[28] A. Bielen, T. Remans, J. Vangronsveld, and A. Cuypers, "The influence of metal stress on the availability and redox state of ascorbate, and possible interference with its cellular functions," International Journal of Molecular Sciences, vol. 14, no. 3, pp. 6382-6413, 2013.

[29] S. K. Panda and S. Choudhury, "Chromium stress in plants," Brazilian Journal of Plant Physiology, vol. 17, no. 1, pp. 95-102, 2005.

[30] J. Zou, M. Wang, W. Jiang, and D. Liu, "Chromium accumulation and its effects on other mineral elements in Amaranthus viridis L," Acta Biologica Cracoviensia Series Botanica, vol. 48, no. 1, pp. 7-12, 2006.

[31] M. Mohanty and H. K. Patra, "Effect of ionic and chelate assisted hexavalent chromium on mung bean seedlings (Vigna radiata L. wilczek. var k-851) during seedling growth," Journal of Stress Physiology \& Biochemistry, vol. 9, no. 2, pp. 232-241, 2013.

[32] H. P. Singh, P. Mahajan, S. Kaur, D. R. Batish, and R. K. Kohli, "Chromium toxicity and tolerance in plants," Environmental Chemistry Letters, vol. 11, no. 3, pp. 229-254, 2013.
[33] S. Gajalakshmi, V. Iswarya, R. Ashwini, G. Divya, S. Mythili, and A. Sathiavelu, "Evaluation of heavy metals in medicinal plants growing in Vellore District," European Journal of Experimental Biology, vol. 2, no. 5, pp. 1457-1461, 2012.

[34] E. L. Hawley, R. A. Deeb, M. C. Kavanaugh, and J. A. Jacobs, "Treatment technologies for chromium(VI)," in Chromium(VI) Handbook, J. Guertin, J. A. Jacobs, and C. P. Avakian, Eds., pp. 275-309, CRC Press, Boca Raton, Fla, USA, 2004.

[35] A. Kumar and S. K. Maiti, "Availability of chromium, nickel and other associated heavy. metals of ultramafic and serpentine soil/rock and in plants," International Journal of Emerging Technology and Advanced Engineering, vol. 3, no. 2, pp. 256-268, 2013.

[36] H. Oliveira, "Chromium as an environmental pollutant: insights on induced plant toxicity," Journal of Botany, vol. 2012, Article ID 375843, 8 pages, 2012.

[37] N. Nematshahi, M. Lahouti, and A. Ganjeali, "Accumulation of chromium and its effect on growth of (Allium cepa cv. Hybrid)," European Journal of Experimental Biology, vol. 2, no. 4, pp. 969974, 2012.

[38] A. K. Shanker, C. Cervantes, H. Loza-Tavera, and S. Avudainayagam, "Chromium toxicity in plants," Environment International, vol. 31, no. 5, pp. 739-753, 2005.

[39] S. Srivastava and R. Jain, "In-situ monitoring of chromium cytotoxicity in sugarcane," Journal of Environmental Biology, vol. 32, no. 6, pp. 759-763, 2011.

[40] A. Fozia, A. Z. Muhammad, A. Muhammad, and M. K. Zafar, "Effect of chromium on growth attributes in sunflower (Helianthus annuus L.)," Journal of Environmental Sciences, vol. 20, no. 12, pp. 1475-1480, 2008.

[41] K. Nath, D. H. Singh, S. Shyam, and Y. K. Sharma, "Effect of chromium and tannery effluent toxicity on metabolism and growth in cowpea (Vigna sinensis L. SaviexHassk) seedling," Research in Environment and Life Sciences, vol. 1, no. 3, pp. 9194, 2008.

[42] I. M. Zeid, "Responses of Phaseolus vulgaris to chromium and cobalt treatments," Biologia Plantarum, vol. 44, no. 1, pp. 111-115, 2001.

[43] S. Samantaray, G. R. Rout, and P. Das, "Role of chromium on plant growth and metabolism," Acta Physiologiae Plantarum, vol. 20, no. 2, pp. 201-212, 1998.

[44] J. Živković, S. RaŽić, J. Arsenijević, and Z. Maksimović, "Heavy metal contents in Veronica species and soil from mountainous areas in Serbia," Journal of the Serbian Chemical Society, vol. 77, no. 7, pp. 959-970, 2012.

[45] J. Liu, M. A. Piñeros, and L. V. Kochian, “The role of aluminum sensing and signaling in plant aluminum resistance," Journal of Integrative Plant Biology, vol. 56, no. 3, pp. 221-230, 2014.

[46] P. S. Kidd and J. Proctor, "Effects of aluminium on the growth and mineral composition of Betula pendula Roth," Journal of Experimental Botany, vol. 51, no. 347, pp. 1057-1066, 2000.

[47] A.-M. B. Påhlsson, "Influence of aluminium on biomass, nutrients, soluble carbohydrates and phenols in beech (Fagus sylvatica)," Physiologia Plantarum, vol. 78, no. 1, pp. 79-84, 1990.

[48] J. F. Ma, P. R. Ryan, and E. Delhaize, "Aluminium tolerance in plants and the complexing role of organic acids," Trends in Plant Science, vol. 6, no. 6, pp. 273-278, 2001.

[49] T. Mossor-Pietraszewska, "Effect of aluminium on plant growth and metabolism," Acta Biochimica Polonica, vol. 48, no. 3, pp. 673-686, 2001. 
[50] G. R. Rout, S. Samantaray, and P. Das, "Aluminium toxicity in plants: a review," Agronomie, vol. 21, no. 1, pp. 3-21, 2001.

[51] F. C. Lidon and M. G. Barreiro, "An overview into aluminum toxicity in maize," Bulgarian Journal of Plant Physiology, vol. 28, no. 3-4, pp. 96-112, 2002.

[52] C. D. Foy, "Soil chemical factors limiting plant root growth," in Limitations to Plant Root Growth, J. L. Hatfield and B. A. Stewart, Eds., vol. 19 of Advances in Soil Sciences, pp. 97-149, Springer, New York, NY, USA, 1992.

[53] F. Steiner, T. Zoz, A. S. P. Junior, D. D. Castagnara, and J. A. L. Dranski, "Effects of aluminum on plant growth and nutrient uptake in young physic nut plants," Semina: Ciências Agrárias, vol. 33, no. 5, pp. 1779-1788, 2012.

[54] S. Silva, "Aluminium toxicity targets in plants," Journal of Botany, vol. 2012, Article ID 219462, 8 pages, 2012.

[55] M. Bian, M. Zhou, D. Sun, and C. Li, "Molecular approaches unravel the mechanism of acid soil tolerance in plants," The Crop Journal, vol. 1, no. 2, pp. 91-104, 2013.

[56] J.-P. Wang, H. Raman, G.-P. Zhang, N. Mendham, and M.-X. Zhou, "Aluminium tolerance in barley (Hordeum vulgare L.): physiological mechanisms, genetics and screening methods," Journal of Zhejiang University. Science. B, vol. 7, no. 10, pp. 769787, 2006.

[57] F. Vardar and M. Ünal, "Aluminum toxicity and resistance in higher plants," Advances in Molecular Biology, vol. 1, pp. 1-12, 2007.

[58] S. A. Bhalerao and D. V. Prabhu, "Aluminium toxicity in plants-a review," Journal of Applicable Chemistry, vol. 2, no. 3, pp. 447-474, 2013.

[59] A. K. M. Z. Hossain, H. Koyama, and T. Hara, "Growth and cell wall properties of two wheat cultivars differing in their sensitivity to aluminum stress," Journal of Plant Physiology, vol. 163, no. 1, pp. 39-47, 2006.

[60] M. F. Batista, I. S. Moscheta, C. M. Bonato, M. A. Batista, O. J. G. de Almeida, and T. T. Inoue, "Aluminum in corn plants: influence on growth and morpho-anatomy of root and leaf," Revista Brasileira de Ciência do Solo, vol. 37, no. 1, pp. 177-187, 2013.

[61] R. J. Bennet, C. M. Breen, and M. V. Fey, "Aluminum induced changes in the morphology of the quiescent center, proximal meristem and growth region of the root of Zea mays," South African Journal of Botany, vol. 51, no. 5, pp. 355-362, 1985.

[62] S. Todorović, Z. Giba, A. Simonović, D. Božić, T. Banjanac, and D. Grubišić, "Manganese effects on in vitro development of lesser centaury [Centaurium pulchellum (Sw.) Druce]," Archives of Biological Sciences, vol. 61, no. 2, pp. 279-283, 2009.

[63] R. Millaleo, M. Reyes-Díaz, A. G. Ivanov, M. L. Mora, and M. Alberdi, "Manganese as essential and toxic element for plants: Transport, accumulation and resistance mechanisms," Journal of Soil Science and Plant Nutrition, vol. 10, no. 4, pp. 476-494, 2010.

[64] A. F. López-Millán, D. R. Ellis, and M. A. Grusak, "Effect of zinc and manganese supply on the activities of superoxide dismutase and carbonic anhydrase in Medicago truncatula wild type and raz mutant plants," Plant Science, vol. 168, no. 4, pp. 1015-1022, 2005.

[65] S. K. Arya and B. K. Roy, "Manganese induced changes in growth, chlorophyll content and antioxidants activity in seedlings of broad bean (Vicia faba L.)," Journal of Environmental Biology, vol. 32, no. 6, pp. 707-711, 2011.
[66] X. Hou and H. J. M. Hou, "Roles of manganese in photosystem II dynamics to irradiations and temperatures," Frontiers in Biology, vol. 8, no. 3, pp. 312-322, 2013.

[67] S. M. Reichman, "The responses of plants to metal toxicity: a review focusing on copper, manganese and zinc," AMEEF Paper 14, Australian Minerals and Energy Environment Foundation, Melbourne, VIC, Australia, 2002.

[68] N. V. Hue and Y. Mai, "Manganese toxicity in watermelon as affected by lime and compost amended to a Hawaiian acid Oxisol," HortScience, vol. 37, no. 4, pp. 656-661, 2002.

[69] N. V. Hue, J. A. Silva, G. Uehara, R. T. Hamasaki, R. Uchida, and P. Bunn, "Managing manganese toxicity in former sugarcane soils on Oahu," Soil and Crop Management SCM-1, University of Hawaii, Honolulu, Hawaii, USA, 1998.

[70] A. González, K. L. Steffen, and J. P. Lynch, "Light and excess manganese. Implications for oxidative stress in common bean," Plant Physiology, vol. 118, no. 2, pp. 493-504, 1998.

[71] V. A. Kavvadias and H. G. Miller, "Manganese and calcium nutrition of Pinus sylvestris and Pinus nigra from two different origins I. Manganese," Forestry, vol. 72, no. 1, pp. 35-45, 1999.

[72] A. Soceanu, V. Magearu, V. Popescu, and N. Matei, "Accumulation of manganese and IRON in citrus fruits," Analele Universitatii Bucuresti: Chimie, vol. 14, no. 1-2, pp. 173-177, 2005.

[73] K. J. Reddy, "Nutrient stress," in Physiology and Molecular Biology of Stress Tolerance in Plants, K. V. Madhava Rao, A. S. Raghavendra, and R. K. Janardhan, Eds., pp. 187-217, Springer, Dordrecht, The Netherlands, 2006.

[74] T. S. Schubert, Manganese Toxicity of Plants in Florida, vol. 353 of Plant Pathology Circular, 1992.

[75] J. D. Maksimović, M. Mojović, V. Maksimović, V. Römheld, and M. Nikolic, "Silicon ameliorates manganese toxicity in cucumber by decreasing hydroxyl radical accumulation in the leaf apoplast," Journal of Experimental Botany, vol. 63, no. 7, pp. 2411-2420, 2012.

[76] M. L. Vitosh, D. D. Warncke, and R. E. Lucas, Secondary and Micronutrients for Vegetables and Field Crops, Michigan State University, Extension Bulletin, E-486, Michigan State University, 1994.

[77] Q. Li, L.-S. Chen, H.-X. Jiang et al., "Effects of manganeseexcess on $\mathrm{CO}_{2}$ assimilation, ribulose-1,5-bisphosphate carboxylase/oxygenase, carbohydrates and photosynthetic electron transport of leaves, and antioxidant systems of leaves and roots in Citrus grandis seedlings," BMC Plant Biology, vol. 10, article 42, 2010.

[78] K. Rezai and T. Farboodnia, "Manganese toxicity effects on chlorophyll content and antioxidant enzymes in pea plant (Pisum sativum L. c.v qazvin)," Agricultural Journal, vol. 3, no. 6, pp. 454-458, 2008.

[79] M. L. Izaguirre-Mayoral and T. R. Sinclair, "Soybean genotypic difference in growth, nutrient accumulation and ultrastructure in response to manganese and iron supply in solution culture," Annals of Botany, vol. 96, no. 1, pp. 149-158, 2005.

[80] D. C. McCain and J. L. Markley, "More manganese accumulates in maple sun leaves than in shade leaves," Plant Physiology, vol. 90, no. 4, pp. 1417-1421, 1989.

[81] R. Hajiboland and B. D. Hasani, "Effect of Cu and Mn toxicity on chlorophyll fluorescence and gas exchange in rice and sunflower under different light intensities,", Journal of Stress Physiology \& Biochemistry, vol. 3, no. 1, pp. 4-17, 2007.

[82] A. H. Wissemeier and W. J. Horst, "Effect of light intensity on manganese toxicity symptoms and callose formation in cowpea 
(Vigna unguiculata (L.) Walp.)," Plant and Soil, vol. 143, no. 2, pp. 299-309, 1992.

[83] Y. C. Lin and C. H. Kao, "Nickel toxicity of rice seedlings: cell wall peroxidase, lignin, and NiSO4-inhibited root growth," Crop, Environment \& Bioinformatics, vol. 2, no. 2, pp. 131-136, 2005.

[84] A. Shafeeq, Z. A. Butt, and S. Muhammad, "Response of nickel pollution on physiological and biochemical attributes of wheat (Triticum aestivum L.) var. Bhakar-02," Pakistan Journal of Botany, vol. 44, no. 1, pp. 111-116, 2012.

[85] M. Poonkothai and B. S. Vijayavathi, "Nickel as an essential element and a toxicant," International Journal of Environmental Sciences, vol. 1, no. 4, pp. 285-288, 2012.

[86] C. Bai, L. Liu, and B. W. Wood, "Nickel affects xylem Sap RNase a and converts RNase A to a urease," BMC Plant Biology, vol. 13, no. 1, article 207, 2013.

[87] Y. A. Iyaka, "Nickel in soils: a review of its distribution and impacts," Scientific Research and Essays, vol. 6, no. 33, pp. 67746777, 2011.

[88] M. R. Khan and M. M. Khan, "Effect of varying concentration of Nickel and Cobalt on the plant growth and yield of Chickpea," Australian Journal of Basic and Applied Sciences, vol. 4, no. 6, pp. 1036-1046, 2010.

[89] C. Aydinalp and S. Marinova, "The effects of heavy metals on seed germination and plant growth on alfalfa plant (Medicago sativa)," Bulgarian Journal of Agricultural Science, vol. 15, no. 4, pp. 347-350, 2009.

[90] S. K. Sethy and S. Ghosh, "Effect of heavy metals on germination of seeds," Journal of Natural Science, Biology and Medicine, vol. 4, no. 2, pp. 272-275, 2013.

[91] F. Al-Qurainy, "Toxicity of heavy metals and their molecular detection on Phaseolus vulgaris (L.)," Australian Journal of Basic and Applied Sciences, vol. 3, no. 3, pp. 3025-3035, 2009.

[92] S. Ishtiaq and S. Mahmood, "Phytotoxicity of nickel and its accumulation in tissues of three Vigna species at their early growth stages," Journal of Applied Botany and Food Quality, vol. 84, no. 2, pp. 223-228, 2011.

[93] I. V. Seregin and A. D. Kozhevnikova, "Physiological role of nickel and its toxic effects on higher plants," Russian Journal of Plant Physiology, vol. 53, no. 2, pp. 257-277, 2006.

[94] I. V. Seregin, A. D. Kozhevnikova, E. M. Kazyumina, and V. B. Ivanov, "Nickel toxicity and distribution in maize roots," Russian Journal of Plant Physiology, vol. 50, no. 5, pp. 711-717, 2003.

[95] P. M. Kopittke, P. J. Dart, and N. W. Menzies, “Toxic effects of low concentrations of $\mathrm{Cu}$ on nodulation of cowpea (Vigna unguiculata)," Environmental Pollution, vol. 145, no. 1, pp. 309315, 2007.

[96] L. L'Huillier, J. D’Auzac, M. Durand, and N. Michaud-Ferriere, "Nickel effects on two maize (Zea mays) cultivars: growth, structure, Ni concentration, and localization," Canadian Journal of Botany, vol. 74, no. 10, pp. 1547-1554, 1996.

[97] R. Yan, S. Gao, W. Yang, M. Cao, S. Wang, and F. Chen, "Nickel toxicity induced antioxidant enzyme and phenylalanine ammonia-lyase activities in Jatropha curcas L. cotyledons," Plant, Soil and Environment, vol. 54, no. 7, pp. 294-300, 2008.

[98] M. H. Siddiqui, M. H. Al-Whaibi, H. M. Ali, A. M. Sakran, M. O. Basalah, and M. Y. Y. AlKhaishany, "Mitigation of nickel stress by the exogenous application of salicylic acid and nitric oxide in wheat," Australian Journal of Crop Science, vol. 7, no. 11, pp. 1780-1788, 2013.
[99] T. V. M. Sreekanth, P. C. Nagajyothi, K. D. Lee, and T. N. V. K. V. Prasad, "Occurrence, physiological responses and toxicity of nickel in plants," International Journal of Environmental Science and Technology, vol. 10, no. 5, pp. 1129-1140, 2013.

[100] F. Ghasemi, R. Heidari, R. Jameii, and L. Purakbar, "Effects of $\mathrm{Ni}^{2+}$ toxicity on Hill reaction and membrane functionality in maize," Journal of Stress Physiology \& Biochemistry, vol. 8, no. 4, pp. 55-61, 2012.

[101] A. Fargašová, “Toxicity comparison of some possible toxic metals ( $\mathrm{Cd}, \mathrm{Cu}, \mathrm{Pb}, \mathrm{Se}, \mathrm{Zn}$ ) on young seedlings of Sinapis alba L," Plant, Soil and Environment, vol. 50, no. 1, pp. 33-38, 2004.

[102] I. Yruela, "Copper in plants: acquisition, transport and interactions," Functional Plant Biology, vol. 36, no. 5, pp. 409-430, 2009.

[103] L. Lombardi and L. Sebastiani, "Copper toxicity in Prunus cerasifera: growth and antioxidant enzymes responses of in vitro grown plants," Plant Science, vol. 168, no. 3, pp. 797-802, 2005.

[104] W. Maksymiec, "Effect of copper on cellular processes in higher plants," Photosynthetica, vol. 34, no. 3, pp. 321-342, 1997.

[105] M. M. Azooz, M. F. Abou-Elhamd, and M. A. Al-Fredan, "Biphasic effect of copper on growth, proline, lipid peroxidation and antioxidant enzyme activities of wheat (Triticum aestivum cv. Hasaawi) at early growing stage," Australian Journal of Crop Science, vol. 6, no. 4, pp. 688-694, 2012.

[106] A. R. Sheldon and N. W. Menzies, "The effect of copper toxicity on the growth and root morphology of Rhodes grass (Chloris gayana Knuth.) in resin buffered solution culture," Plant and Soil, vol. 278, no. 1-2, pp. 341-349, 2005.

[107] A. M. Nicholls and T. K. Mal, "Effects of lead and copper exposure on growth of an invasive weed, Lythrum salicaria L. (Purple Loosestrife)," Ohio Journal of Science, vol. 103, no. 5, pp. 129-133, 2003.

[108] P. Y. Yau, C. F. Loh, and I. A. R. Azmil, "Copper toxicity of clove (Syzygium aromaticum ( L.) Merr. and Perryl) seedlings," Mardi Research Journal, vol. 19, no. 1, pp. 49-53, 1991.

[109] B. Alaoui-Sossé, P. Genet, F. Vinit-Dunand, M.-L. Toussaint, D. Epron, and P.-M. Badot, "Effect of copper on growth in cucumber plants (Cucumis sativus) and its relationships with carbohydrate accumulation and changes in ion contents," Plant Science, vol. 166, no. 5, pp. 1213-1218, 2004.

[110] M. H. Assareh, A. Shariat, and A. Ghamari-Zare, "Seedling response of three Eucalyptus species to copper and zinc toxic concentrations," Caspian Journal of Environmental Sciences, vol. 6, no. 2, pp. 97-103, 2008.

[111] C. C. Tsay, L. W. Wang, and Y. R. Chen, "Plant response to $\mathrm{Cu}$ toxicity," Taiwana, vol. 40, no. 2, pp. 173-181, 1995.

[112] L.-M. Chen, C. C. Lin, and C. H. Kao, "Copper toxicity in rice seedlings: changes in antioxidative enzyme activities, $\mathrm{H}_{2} \mathrm{O}_{2}$ level, and cell wall peroxidase activity in roots," Botanical Bulletin of Academia Sinica, vol. 41, no. 2, pp. 99-103, 2000.

[113] S. Doncheva and Z. Stoyanova, "Plant response to copper and zinc hydroxidesulphate and hydroxidecarbonate used as an alternative copper and zinc sources in mineral nutrition," Romanian Agricultural Research, no. 7-8, pp. 15-23, 2007.

[114] S. Mishra and R. S. Dubey, "Heavy metal toxicity induced alterations in photosynthetic metabolism in plants," in Handbook of Photosynthesis, M. Pessarakli, Ed., pp. 845-863, CRC Press, Taylor \& Francis, New York, NY, USA, 2nd edition, 2005.

[115] F. Yurekli and Z. B. Porgali, "The effects of excessive exposure to copper in bean plants," Acta Biologica Cracoviensia Series Botanica, vol. 48, no. 2, pp. 7-13, 2006. 
[116] E. Pätsikkä, E.-M. Aro, and E. Tyystjärvi, "Increase in the quantum yield of photoinhibition contributes to copper toxicity in vivo," Plant Physiology, vol. 117, no. 2, pp. 619-627, 1998.

[117] M. Peško and K. Král'ová, "Physiological response of Brassica napus L. plants to $\mathrm{Cu}$ (II) treatment," Proceedings of ECOpole, vol. 7, no. 1, pp. 155-161, 2013.

[118] R. K. Sharma, S. Devi, and P. P. dan Dhyani, "Comparative assessment of the toxic effects of copper and cypermethrin using seeds of Spinacia Oleracea L. plants," Tropical Ecology, vol. 51, no. 2, supplement, pp. 375-387, 2010.

[119] C. Mediouni, O. Benzarti, B. Tray, M. H. Ghorbel, and F. Jemal, "Cadmium and copper toxicity for tomato seedlings," Agronomy for Sustainable Development, vol. 26, no. 4, pp. 227-232, 2006.

[120] R. Sagardoy, F. Morales, A.-F. López-Millán, A. Abadía, and J. Abadía, "Effects of zinc toxicity on sugar beet (Beta vulgaris L.) plants grown in hydroponics," Plant Biology, vol. 11, no. 3, pp. 339-350, 2009.

[121] S. K. Gupta, A. K. Rai, S. S. Kanwar, and T. R. Sharma, "Comparative analysis of zinc finger proteins involved in plant disease resistance," PLoS ONE, vol. 7, no. 8, Article ID e42578, 2012.

[122] S. R Mousavi, M. Galavi, and M. Rezaei, "Zinc (Zn) importance for crop production-a review," International Journal of Agronomy and Plant Production, vol. 4, no. 1, pp. 64-68, 2013.

[123] A. Kleckerova, P. Sobrova, O. Krystofova et al., "Cadmium(II) and zinc(II) ions effects on maize plants revealed by spectroscopy and electrochemistry," International Journal of Electrochemical Science, vol. 6, no. 12, pp. 6011-6031, 2011.

[124] M. R. Broadley, P. J. White, J. P. Hammond, I. Zelko, and A. Lux, "Zinc in plants," New Phytologist, vol. 173, no. 4, pp. 677-702, 2007.

[125] A. S. Bucher and M. K. Schenk, "Toxicity level for phytoavailable zinc in compost-peat substrates," Scientia Horticulturae, vol. 83, no. 3-4, pp. 339-352, 2000.

[126] F. Aref, "Concentration and uptake of zinc and boron in corn leaf as affected by zinc sulfate and boric acid fertilizers in a deficient soil," Life Science Journal, vol. 8, no. 1, pp. 26-32, 2011.

[127] S. K. Yadav, "Heavy metals toxicity in plants: an overview on the role of glutathione and phytochelatins in heavy metal stress tolerance of plants," South African Journal of Botany, vol. 76, no. 2, pp. 167-179, 2010.

[128] A. Baran, "Assessment of Zea mays sensitivity to toxic content of zinc in soil," Polish Journal of Environmental Studies, vol. 22, no. 1, pp. 77-83, 2013.

[129] R. Sivasankar, R. Kalaikandhan, and P. Vijayarengan, "Phytoremediating capability and nutrient status of four plant species under zinc stress," International Journal of Research in Plant Science, vol. 2, no. 1, pp. 8-15, 2012.

[130] Y. Fukao, A. Ferjani, R. Tomioka et al., "iTRAQ analysis reveals mechanisms of growth defects due to excess zinc in Arabidopsis," Plant Physiology, vol. 155, no. 4, pp. 1893-1907, 2011.

[131] S. C. Miyasaka, R. T. Hamasaki, and R. S. Pena, Nutrient Deficiencies and Excesses in Taro, Soil and Crop Management, SCM-4, 2002.

[132] P. K. Mishra and V. Prakash, "Response of non-enzymatic antioxidants to zinc Induced stress at different $\mathrm{pH}$ in Glycine max L. cv. Merrill," Academic Journal of Plant Sciences, vol. 3, no. 1, pp. 1-10, 2010.

[133] Z. Hosseini and L. Poorakbar, "Zinc toxicity on antioxidative response in (Zea mays L.) at two different $\mathrm{pH}$," Journal of Stress Physiology \& Biochemistry, vol. 9, pp. 66-73, 2013.
[134] A. Vassilev, A. Nikolova, L. Koleva, and F. Lidon, "Effects of excess $\mathrm{Zn}$ on growth and photosynthetic performance of young bean plants," Journal of Phytology, vol. 3, no. 6, pp. 58-62, 2011.

[135] H. Mirshekali, H. Hadi, R. Amirnia, and H. Khodaverdiloo, "Effect of zinc toxicity on plant productivity, chlorophyll and $\mathrm{Zn}$ contents of sorghum (Sorghum bicolor) and common lambsquarter (Chenopodium album)," International Journal of Agriculture: Research and Review, vol. 2, no. 3, pp. 247-254, 2012.

[136] F. S. lalelou, J. Shafagh-Kolvanagh, and M. Fateh, "Effect of various concentrations of zinc on chlorophyll, starch, soluble sugars and proline in naked pumpkin (Cucurbita pepo)," International Journal of Farming and Allied Sciences, vol. 2, no. 24, pp. 11981202, 2013.

[137] T. Tsonev and F. J. C. Lidon, "Zinc in plants-an overview," Emirates Journal of Food and Agriculture, vol. 24, no. 4, pp. 322333, 2012.

[138] E. O. Oladele, P. G. C. Odeigah, and I. A. Taiwo, "The genotoxic effect of lead and zinc on bambara groundnut (Vigna subterranean)," African Journal of Environmental Science and Technology, vol. 7, no. 1, pp. 9-13, 2013.

[139] E. C. Truta, D. N. Gherghel, I. C. I. Bara, and G. V. Vochita, "Zinc-induced genotoxic effects in root meristems of barley seedlings," Notulae Botanicae Horti Agrobotanici Cluj-Napoca, vol. 41, no. 1, pp. 150-156, 2013.

[140] V. Todeschini, G. Lingua, G. D’Agostino, F. Carniato, E. Roccotiello, and G. Berta, "Effects of high zinc concentration on poplar leaves: a morphological and biochemical study," Environmental and Experimental Botany, vol. 71, no. 1, pp. 5056, 2011.

[141] P. Vijayarengan and G. Mahalakshmi, "Zinc toxicity in tomato plants," World Applied Sciences Journal, vol. 24, no. 5, pp. 649653, 2013.

[142] H. L. Wong, T. Sakamoto, T. Kawasaki, K. Umemura, and K. Shimamoto, "Down-regulation of metallothionein, a reactive oxygen scavenger, by the small GTPase OsRacl in rice," Plant Physiology, vol. 135, no. 3, pp. 1447-1456, 2004.

[143] E. Harada, J.-A. Kim, A. J. Meyer, R. Hell, S. Clemens, and Y.-E. Choi, "Expression profiling of tobacco leaf trichomes identifies genes for biotic and abiotic stresses," Plant and Cell Physiology, vol. 51, no. 10, pp. 1627-1637, 2010.

[144] S. Lee, J. S. Moon, L. L. Domier, and S. S. Korban, "Molecular characterization of phytochelatin synthase expression in transgenic Arabidopsis," Plant Physiology and Biochemistry, vol. 40, no. 9, pp. 727-733, 2002.

[145] M. T. Hauser, "Molecular basis of natural variation and environmental control of trichome patterning," Frontiers in Plant Science, vol. 5, no. 320, pp. 1-7, 2014.

[146] S. S. Sharma and K.-J. Dietz, "The significance of amino acids and amino acid-derived molecules in plant responses and adaptation to heavy metal stress," The Journal of Experimental Botany, vol. 57, no. 4, pp. 711-726, 2006.

[147] M. Mourato, R. Reis, and L. L. Martins, "Characterization of plant antioxidative system in response to abiotic stresses: a focus on heavy metal toxicity," in Advances in Selected Plant Physiology Aspects, G. Montanaro and B. Dichio, Eds., pp. 23-44, InTech, Vienna, Austria, 2012, http://hdl.handle.net/10400.5/4410.

[148] A. Michalak, "Phenolic compounds and their antioxidant activity in plants growing under heavy metal stress," Polish Journal of Environmental Studies, vol. 15, no. 4, pp. 523-530, 2006. 
[149] L. Rastgoo, A. Alemzadeh, and A. Afsharifar, "Isolation of two novel isoforms encoding zinc- and copper-transporting P1BATPase from Gouan (Aeluropus littoralis)," Plant Omics Journal, vol. 4, no. 7, pp. 377-383, 2011.

[150] R. Solanki and R. Dhankhar, "Biochemical changes and adaptive strategies of plants under heavy metal stress," Biologia, vol. 66, no. 2, pp. 195-204, 2011.

[151] S. Lee, J. S. Moon, T. S. Ko, D. Petros, P. B. Goldsbrough, and S. S. Korban, "Overexpression of Arabidopsis phytochelatin synthase paradoxically leads to hypersensitivity to cadmium stress," Plant Physiology, vol. 131, no. 2, pp. 656-663, 2003.

[152] L. Chen, Y. Guo, L. Yang, and Q. Wang, "Synergistic defensive mechanism of phytochelatins and antioxidative enzymes in Brassica chinensis L. against Cd stress," Chinese Science Bulletin, vol. 53, no. 10, pp. 1503-1511, 2008.

[153] H.-C. Wang, J.-S. Wu, J.-C. Chia, C.-C. Yang, Y.-J. Wu, and R.-H. Juang, "Phytochelatin synthase is regulated by protein phosphorylation at a threonine residue near its catalytic site," Journal of Agricultural and Food Chemistry, vol. 57, no. 16, pp. 7348-7355, 2009.

[154] D. Shukla, M. Tiwari, R. D. Tripathi, P. Nath, and P. K. Trivedi, "Synthetic phytochelatins complement a phytochelatindeficient Arabidopsis mutant and enhance the accumulation of heavy metal(loid)s," Biochemical and Biophysical Research Communications, vol. 434, no. 3, pp. 664-669, 2013.

[155] D. Gupta, H. Vandenhove, and M. Inouhe, "Role of phytochelatins in heavy metal stress and detoxification mechanisms in plants," in Heavy Metal Stress in Plants, pp. 73-94, Springer, Berlin, Germany, 2013.

[156] O. K. Vatamaniuk, E. A. Bucher, J. T. Ward, and P. A. Rea, "A new pathway for heavy metal detoxification in animals. Phytochelatin synthase is required for cadmium tolerance in Caenorhabditis elegans," Journal of Biological Chemistry, vol. 276, no. 24, pp. 20817-20820, 2001.

[157] J. G. Bundy, P. Kille, M. Liebeke, and D. J. Spurgeon, "Metallothioneins may not be enough - the role of phytochelatins in invertebrate metal detoxification," Environmental Science and Technology, vol. 48, no. 2, pp. 885-886, 2014.

[158] L. Zagorchev, C. E. Seal, I. Kranner, and M. Odjakova, "A central role for thiols in plant tolerance to abiotic stress," International Journal of Molecular Sciences, vol. 14, no. 4, pp. 7405-7432, 2013.

[159] H. Saba, P. Jyoti, and S. Neha, "Mycorrhizae and phytochelators as remedy in heavy metal contaminated land remediation," International Research Journal of Environment Sciences, vol. 2, no. 1, pp. 74-78, 2013.

[160] W.-Y. Song, D. G. Mendoza-Cózatl, Y. Lee et al., "Phytochelatinmetal(loid) transport into vacuoles shows different substrate preferences in barley and Arabidopsis," Plant, Cell and Environment, vol. 37, no. 5, pp. 1192-1201, 2014.

[161] W. E. Rauser, "Phytochelatins and related peptides. Structure, biosynthesis, and function," Plant Physiology, vol. 109, no. 4, pp. 1141-1149, 1995.

[162] C. S. Cobbett, "Phytochelatins and their roles in heavy metal detoxification," Plant Physiology, vol. 123, no. 3, pp. 825-832, 2000.

[163] P. Kotrba, T. Macek, and T. Ruml, "Heavy metal-binding peptides and proteins in plants. A review," Collection of Czechoslovak Chemical Communications, vol. 64, no. 7, pp. 1057-1086, 1999.

[164] P. Thangavel, S. Long, and R. Minocha, "Changes in phytochelatins and their biosynthetic intermediates in red spruce
(Picea rubens Sarg.) cell suspension cultures under cadmium and zinc stress," Plant Cell, Tissue and Organ Culture, vol. 88, no. 2, pp. 201-216, 2007.

[165] F. Yurekli and Z. Kucukbay, "Synthesis of phytochelatins in Helianthus annuus is enhanced by cadmium nitrate," Acta Botanica Croatica, vol. 62, no. 1, pp. 21-25, 2003.

[166] F. Fidalgo, M. Azenha, A. F. Silva et al., "Copper-induced stress in Solanum nigrum L. and antioxidant defense system response," Food and Energy Security, vol. 2, no. 1, pp. 70-80, 2013.

[167] B. L. Batista, M. Nigar, A. Mestrot et al., "Identification and quantification of phytochelatins in roots of rice to long-term exposure: evidence of individual role on arsenic accumulation and translocation," The Journal of Experimental Botany, vol. 65, no. 6, pp. 1467-1479, 2014.

[168] S. Heiss, A. Wachter, J. Bogs, C. Cobbett, and T. Rausch, "Phytochelatin synthase (PCS) protein is induced in Brassica juncea leaves after prolonged Cd exposure," Journal of Experimental Botany, vol. 54, no. 389, pp. 1833-1839, 2003.

[169] G. Szalai, A. Krantev, R. Yordanova, L. P. Popova, and T. Janda, "Influence of salicylic acid on phytochelatin synthesis in Zea mays during Cd stress," Turkish Journal of Botany, vol. 37, no. 4, pp. 708-714, 2013.

[170] Z. C. Zhang, B. X. Chen, and B. S. Qiu, "Phytochelatin synthesis plays a similar role in shoots of the cadmium hyperaccumulator Sedum alfredii as in non-resistant plants," Plant, Cell and Environment, vol. 33, no. 8, pp. 1248-1255, 2010.

[171] S. Hentz, J. McComb, G. Miller, M. Begonia, and G. Begonia, "Cadmium uptake, growth and phytochelatin contents of Triticum aestivum in response to various concentrations of cadmium," World Environment, vol. 2, no. 3, pp. 44-50, 2012.

[172] M. Inouhe, "Phytochelatins," Brazilian Journal of Plant Physiology, vol. 17, no. 1, pp. 65-78, 2005.

[173] P. Brunetti, L. Zanella, A. Proia et al., "Cadmium tolerance and phytochelatin content of Arabidopsis seedlings over-expressing the phytochelatin synthase gene AtPCS1," Journal of Experimental Botany, vol. 62, no. 15, pp. 5509-5519, 2011.

[174] A. Piechalak, B. Tomaszewska, D. Baralkiewicz, and A. Malecka, "Accumulation and detoxification of lead ions in legumes," Phytochemistry, vol. 60, no. 2, pp. 153-162, 2002.

[175] G. M. Shen, C. Zhu, and Q. Z. Du, "Genome-wide identification of PHYTOCHELATIN and PHYTOCH_SYNTH domaincontaining phytochelatin family from rice," Electronic Journal of Biology, vol. 6, no. 3, pp. 73-79, 2010.

[176] B. N. Postrigan, A. B. Knyazev, B. R. Kuluev, O. I. Yakhin, and A. V. Chemeris, "Expression of the synthetic phytochelatin gene in tobacco," Russian Journal of Plant Physiology, vol. 59, no. 2, pp. 275-280, 2012.

[177] J. Guo, W. Xu, and M. Ma, “The assembly of metals chelation by thiols and vacuolar compartmentalization conferred increased tolerance to and accumulation of cadmium and arsenic in transgenic Arabidopsis thaliana," Journal of Hazardous Materials, vol. 199-200, pp. 309-313, 2012.

[178] M. Margoshes and B. L. Vallee, "A cadmium protein from equine kidney cortex," Journal of the American Chemical Society, vol. 79, no. 17, pp. 4813-4814, 1957.

[179] J. Du, J.-L. Yang, and C.-H. Li, "Advances in metallotionein studies in forest trees," Plant OMICS, vol. 5, no. 1, pp. 46-51, 2012.

[180] A. Macovei, L. Ventura, M. Donà, M. Faè, A. Balestrazzi, and D. Carbonera, "Effects of heavy metal treatments on metallothionein expression profiles in white poplar (Populus albaL.) cell 
suspension cultures," Analele Universitătii din Oradea-Fascicula Biologie, vol. 18, no. 2, pp. 274-279, 2010.

[181] Y. Cai and L. Q. Ma, "Metal tolerance accumulation and detoxication in plants with emphasis on arsenic in terrestrial plants," in Proceedings of the ACS Symposium Series 835 on Biogeochemistry of Environmentally Important Trace Elements, Y. Cai and O. C. Btaids, Eds., pp. 95-114, American Chemical Society, 2003.

[182] J. A. C. Verkleij, F. E. C. Sneller, and H. Schat, "Metallothioneins and phytochelatins: ecophysiological aspects," in Sulphur in Plants, Y. P. Abrol and A. Ahmad, Eds., pp. 163-176, Springer, Dordrecht, Netherlands, 2003.

[183] Z. Yang and C. Chu, "Towards understanding plant response to heavy metal stress," in Abiotic Stress in Plants-Mechanisms and Adaptations, pp. 59-78, InTech, Shanghai, China, 2011.

[184] O. I. Leszczyszyn, H. T. Imam, and C. A. Blindauer, "Diversity and distribution of plant metallothioneins: a review of structure, properties and functions," Metallomics, vol. 5, no. 9, pp. 11461169, 2013.

[185] J. L. Guo, L. P. Xu, Y. C. Su et al., “ScMT2-1-3, a metallothionein gene of sugarcane, plays an important role in the regulation of heavy metal tolerance/accumulation," BioMed Research International, vol. 2013, Article ID 904769, 12 pages, 2013.

[186] A. Kohler, D. Blaudez, M. Chalot, and F. Martin, "Cloning and expression of multiple metallothioneins from hybrid poplar," New Phytologist, vol. 164, no. 1, pp. 83-93, 2004.

[187] S. Mishra and R. S. Dubey, "Heavy metal uptake and detoxification mechanisms in plants," International Journal of Agricultural Research, vol. 1, no. 2, pp. 122-141, 2006.

[188] A. K. Grennan, "Metallothioneins, a diverse protein family," Plant Physiology, vol. 155, no. 4, pp. 1750-1751, 2011.

[189] G. Y. Huang and Y. S. Wang, "Expression analysis of type 2 metallothionein gene in mangrove species (Bruguiera gymnorrhiza) under heavy metal stress," Chemosphere, vol. 77, no. 7, pp. 10261029, 2009.

[190] E. Freisinger, "Structural features specific to plant metallothioneins," Journal of Biological Inorganic Chemistry, vol. 16, no. 7, pp. 1035-1045, 2011.

[191] M. García-Hernández, A. Murphy, and L. Taiz, "Metallothioneins 1 and 2 have distinct but overlapping expression patterns in Arabidopsis," Plant Physiology, vol. 118, no. 2, pp. 387-397, 1998.

[192] Z. Yang, Y. Wu, Y. Li, H.-Q. Ling, and C. Chu, "OsMTla, a type 1 metallothionein, plays the pivotal role in zinc homeostasis and drought tolerance in rice," Plant Molecular Biology, vol. 70, no. 1-2, pp. 219-229, 2009.

[193] J. N. Hegelund, M. Schiller, T. Kichey et al., "Barley metallothioneins: MT3 and MT4 are localized in the grain aleurone layer and show differential zinc binding," Plant Physiology, vol. 159, no. 3, pp. 1125-1137, 2012.

[194] M. A. Pagani, M. Tomas, J. Carrillo et al., "The response of the different soybean metallothionein isoforms to cadmium intoxication," Journal of Inorganic Biochemistry, vol. 117, pp. 306-315, 2012.

[195] G. Dajbrowska, A. Mierek-Adamska, and A. Goc, "Characterisation of Brassica napus L. metallothionein genes (BnMTs) expression in organs and during seed germination," Australian Journal of Crop Science, vol. 7, no. 9, pp. 1324-1332, 2013.

[196] Y. Xia, Y. Qi, Y. Yuan et al., "Overexpression of Elsholtzia haichowensis metallothionein 1 (EhMT1) in tobacco plants enhances copper tolerance and accumulation in root cytoplasm and decreases hydrogen peroxide production," Journal of Hazardous Materials, vol. 233-234, pp. 65-71, 2012.

[197] G. Kumar, H. R. Kushwaha, V. Panjabi-Sabharwal et al., "Clustered metallothionein genes are co-regulated in rice and ectopic expression of OsMTle-P confers multiple abiotic stress tolerance in tobacco via ROS scavenging," BMC Plant Biology, vol. 12, article 107, 2012.

[198] A. Zhigang, L. Cuijie, Z. Yuangang et al., "Expression of BjMT2, a metallothionein 2 from Brassica juncea, increases copper and cadmium tolerance in Escherichia coli and Arabidopsis thaliana, but inhibits root elongation in Arabidopsis thaliana seedlings," Journal of Experimental Botany, vol. 57, no. 14, pp. 3575-3582, 2006.

[199] D. Pavlíková, M. Pavlík, L. Staszková, P. Tlustoš, J. Száková, and J. Balík, "The effect of potentially toxic elements and sewage sludge on the activity of regulatory enzyme glutamate kinase," Plant, Soil and Environment, vol. 53, no. 5, pp. 201-206, 2007.

[200] S. Zarei, A. A. Ehsanpour, and J. Abbaspour, "The role of over expression of P5CS gene on proline, catalase, ascorbate peroxidase activity and lipid peroxidation of transgenic tobacco (Nicotiana tabacum L.) plant under in vitro drought stress," Journal of Cell and Molecular Research, vol. 4, no. 1, pp. 43-49, 2012.

[201] D. J. Burritt, "Proline and the cryopreservation of plant tissues: functions and practical applications," in Current Frontiers in Cryopreservation, I. Katkov, Ed., pp. 415-426, InTech, 2012.

[202] L. Szabados and A. Savouré, "Proline: a multifunctional amino acid," Trends in Plant Science, vol. 15, no. 2, pp. 89-97, 2010.

[203] S. Clemens, "Toxic metal accumulation, responses to exposure and mechanisms of tolerance in plants," Biochimie, vol. 88, no. 11, pp. 1707-1719, 2006.

[204] B. N. Tripathi and J. P. Gaur, "Relationship between copperand zinc-induced oxidative stress and proline accumulation in Scenedesmus sp," Planta, vol. 219, no. 3, pp. 397-404, 2004.

[205] L. N. Karimi, M. Khanahmadi, and B. Moradi, "Accumulation and phytotoxicity of lead in Cynara scolymus," Indian Journal of Science and Technology, vol. 5, no. 11, pp. 3634-3641, 2012.

[206] M. Gohari, A. R. Habib-Zadeh, and M. Khayat, "Assessing the intensity of tolerance to lead and its effect on amount of protein and proline in root and aerial parts of two varieties of rape seed (Brassica napus L.)," Journal of Basic and Applied Scientific Research, vol. 2, no. 1, pp. 935-938, 2012.

[207] K. Leskó and L. Simon-Sarkadi, "Effect of cadmium stress on amino acid and polyamine content of wheat seedlings," Periodica Polytechnica: Chemical Engineering, vol. 46, no. 1-2, pp. 65-71, 2002.

[208] G. K. Handique and A. K. Handique, "Proline accumulation in lemongrass (Cymbopogon flexuosus Stapf.) due to heavy metal stress," Journal of Environmental Biology, vol. 30, no. 2, pp. 299302, 2009.

[209] N. Nikolić, D. Kojic, A. Pilipovic et al., "Responses of hybrid poplar to cadmium stress: photosynthetic characteristics, cadmium and proline accumulation, and antioxidant enzyme activity," Acta Biologica Cracoviensia Series Botanica, vol. 50, no. 2, pp. 95-103, 2008.

[210] F. K. Zengin and S. Kirbag, "Effects of copper on chlorophyll, proline, protein and abscisic acid level of sunflower (Helianthus annuus L.) seedlings," Journal of Environmental Biology, vol. 28, no. 3, pp. 561-566, 2007.

[211] P. Theriappan, A. K. Gupta, and P. Dhasarrathan, "Accumulation of proline under salinity and heavy metal stress in cauliflower 
seedlings," Journal of Applied Sciences and Environmental Management, vol. 15, no. 2, pp. 251-255, 2011.

[212] P. P. Pant, A. K. Tripathi, and V. Dwivedi, "Effect of heavy metals on some biochemical parameters of sal (Shorea robusta) seedling at nursery level, Doon Valley, India," Journal of Agricultural Science, vol. 2, no. 1, pp. 45-51, 2011.

[213] V. Kumar, G. Awasthi, and P. K. Chauhan, "Cu and Zn tolerance and responses of the biochemical and physiochemical system of wheat," Journal of Stress Physiology \& Biochemistry, vol. 8, no. 3, pp. 203-213, 2012.

[214] M. Ruscitti, M. Arango, M. Ronco, and J. Beltrano, "Inoculation with mycorrhizal fungi modifies praline metabolism and increases chromium tolerance in pepper plants (Capsicum annuum L.)," Brazilian Journal of Plant Physiology, vol. 23, no. 1, pp. 15-25, 2011.

[215] S. Hayat, Q. Hayat, M. N. Alyemeni, and A. Ahmad, "Proline enhances antioxidative enzyme activity, photosynthesis and yield of Cicer arietinum L. exposed to cadmium stress," Acta Botanica Croatica, vol. 72, no. 2, pp. 323-335, 2013.

[216] M. A. Shahid, R. M. Balal, M. A. Pervez et al., "Exogenous proline and proline-enriched Lolium perenne leaf extract protects against phytotoxic effects of nickel and salinity in Pisum sativum by altering polyamine metabolism in leaves," Turkish Journal of Botany, vol. 38, no. 5, pp. 914-926, 2014.

[217] S. Hayat, Q. Hayat, M. N. Alyemeni, A. S. Wani, J. Pichtel, and A. Ahmad, "Role of proline under changing environments: a review," Plant Signaling \& Behavior, vol. 7, no. 11, pp. 1456-1466, 2012.

[218] F. Wang, B. Zeng, Z. Sun, and C. Zhu, "Relationship between proline and $\mathrm{Hg}^{2+}$-induced oxidative stress in a tolerant rice mutant," Archives of Environmental Contamination and Toxicology, vol. 56, no. 4, pp. 723-731, 2009.

[219] J. F. Johansson, L. R. Paul, and R. D. Finlay, "Microbial interactions in the mycorrhizosphere and their significance for sustainable agriculture," FEMS Microbiology Ecology, vol. 48, no. 1, pp. 1-13, 2004.

[220] H. M. Leung, Z. H. Ye, and M. H. Wong, "Survival strategies of plants associated with arbuscular mycorrhizal fungi on toxic mine tailings," Chemosphere, vol. 66, no. 5, pp. 905-915, 2007.

[221] H. Upadhyaya, S. K. Panda, M. K. Bhattacharjee, and S. Dutta, "Role of arbuscular mycorrhiza in heavy metal tolerance in plants: prospects for phytoremediation," Journal of Phytology, vol. 2 , no. 7, pp. 16-27, 2010.

[222] K. Turnau, "Heavy metal content and localization in mycorrhizal Euphorbia cyparissias zinc wastes in Southern Poland," Acta Societatis Botanicorum Poloniae, vol. 67, no. 1, pp. 105-113, 1998.

[223] U. Hildebrandt, M. Regvar, and H. Bothe, "Arbuscular mycorrhiza and heavy metal tolerance," Phytochemistry, vol. 68, no. 1, pp. 139-146, 2007.

[224] S. A. L. de Andrade and A. P. D. da Silveira, "Mycorrhiza influence on maize development under Cd stress and P supply," Brazilian Journal of Plant Physiology, vol. 20, no. 1, pp. 39-50, 2008.

[225] N. Garg and S. Chandel, "Arbuscular mycorrhizal networks: process and functions. A review," Agronomy for Sustainable Development, vol. 30, no. 3, pp. 581-599, 2010.

[226] A. Aloui, G. Recorbet, F. Robert et al., "Arbuscular mycorrhizal symbiosis elicits shoot proteome changes that are modified during cadmium stress alleviation in Medicago truncatula," BMC Plant Biology, vol. 11, article 75, 2011.
[227] K. Mohammadi, S. Khalesro, Y. Sohrabi, and G. Heidari, "A review: beneficial effects of the mycorrhizal fungi for plant growth," Journal of Applied Environmental and Biological Sciences, vol. 1, no. 9, pp. 310-319, 2011.

[228] T. Takács, B. Biró, and I. Vörös, “Arbuscular mycorrhizal effect on heavy metal uptake of ryegrass (Lolium perenne L.) in pot culture with polluted soil," in Plant Nutrition: Food Security and Sustainability of Agro-Ecosystems through Basic and Applied Research, W. W. J. Horst, M. K. Scheck, A. Bürkert et al., Eds., Developments in Plant and Soil Sciences, pp. 480-481, Kluwer Academic Publishers, Dordrecht, Netherlands, 2001.

[229] C. K. Shivakumar, C. Hemavani, B. Thippeswamy, and M. Krishnappa, "Effect of inoculation with arbuscular mycorrhizal fungi on green gram grown in soil containing heavy metal zinc," Journal of Experimental Sciences, vol. 2, no. 10, pp. 17-21, 2011.

[230] S. A. Bano and D. Ashfaq, "Role of mycorrhiza to reduce heavy metal stress," Natural Science, vol. 5, no. 12, pp. 16-20, 2013.

[231] Y. Huang, S. Tao, and Y.-J. Chen, "The role of arbuscular mycorrhiza on change of heavy metal speciation in rhizosphere of maize in wastewater irrigated agriculture soil," Journal of Environmental Sciences, vol. 17, no. 2, pp. 276-280, 2005.

[232] A. K. J. Abad and J. Khara, "Effect of cadmium toxicity on the level of lipid peroxidation and antioxidative enzymes activity in wheat plants colonized by arbuscular mycorrhizal fungi," Pakistan Journal of Biological Sciences, vol. 10, no. 14, pp. 24132417, 2007.

[233] N. Garg and N. Aggarwal, "Effect of mycorrhizal inoculations on heavy metal uptake and stress alleviation of Cajanus cajan (L.) Millsp. genotypes grown in cadmium and lead contaminated soils," Plant Growth Regulation, vol. 66, no. 1, pp. 9-26, 2012.

[234] S. Farshian, J. Khara, and P. Malekzadeh, "Influence of arbuscular mycorrhizal fungus (Glomus etunicatum) with lettuce plants under zinc toxicity in nutrient solution," Pakistan Journal of Biological Sciences, vol. 10, no. 14, pp. 2363-2367, 2007.

[235] R. Rahmaty and J. Khara, "Effects of vesicular arbuscular mycorrhiza Glomus intraradices on photosynthetic pigments, antioxidant enzymes, lipid peroxidation, and chromium accumulation in maize plants treated with chromium," Turkish Journal of Biology, vol. 35, no. 1, pp. 51-58, 2011.

[236] T. S. Abdelmoneim, T. A. A. Moussa, O. A. Almaghrabi, and I. Abdelbagi, "Investigation the effect of arbuscular mycorrhizal fungi on the tolerance of maize plant to heavy metals stress," Life Science Journal, vol. 11, no. 4, pp. 255-263, 2014.

[237] S. Amanifar, N. Aliasgharzad, M. Toorchi, and M. Zarei, "Lead phytotoxicity on some plant growth parameters and proline accumulation in mycorrhizal tomato (Lycopersicon esculentum L.)," International Journal of Biosciences, vol. 4, no. 10, pp. 80-88, 2014.

[238] S. A. Bhalerao, "Arbuscular mycorrhizal fungi: a potential biotechnology tool for phytoremediation of heavy metal contaminated soils," International Journal of Science and Nature, vol. 4, no. 1, pp. 1-15, 2013.

[239] I. Saxena and G. S. Shekhawat, "Nitric oxide (NO) in alleviation of heavy metal induced phytotoxicity and its role in protein nitration," Nitric Oxide: Biology and Chemistry, vol. 32, pp. 1320, 2013. 

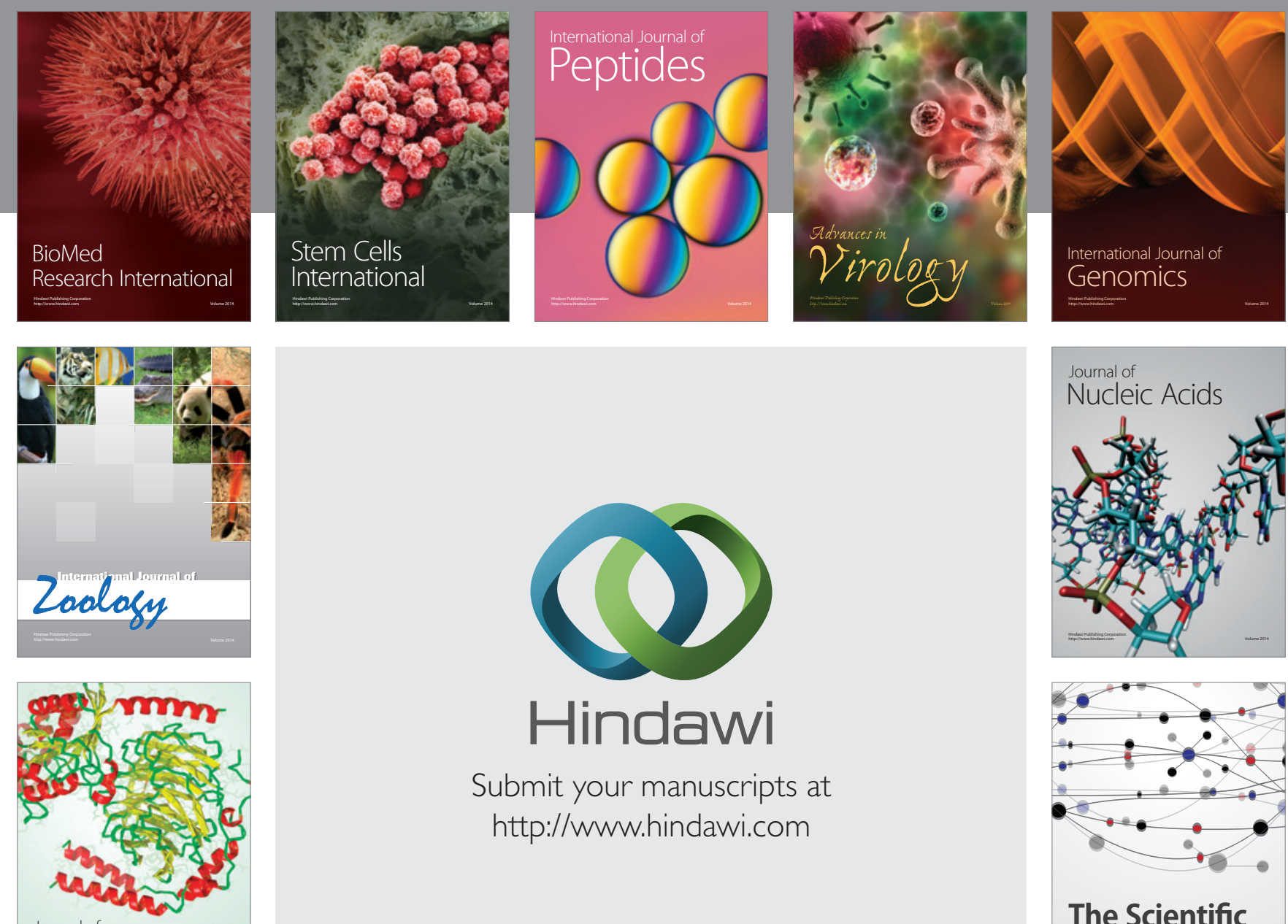

Submit your manuscripts at

http://www.hindawi.com

Journal of
Signal Transduction
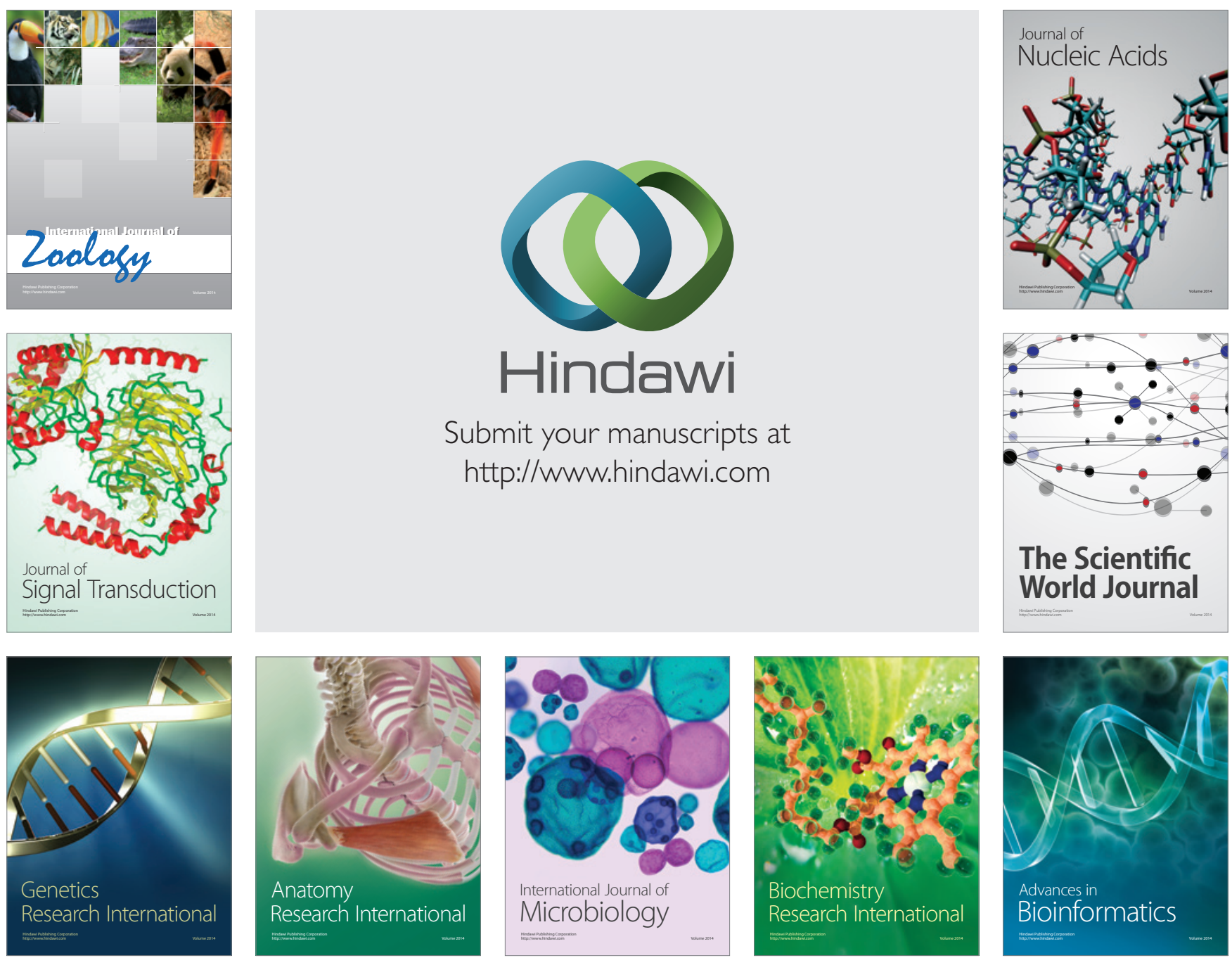

The Scientific World Journal
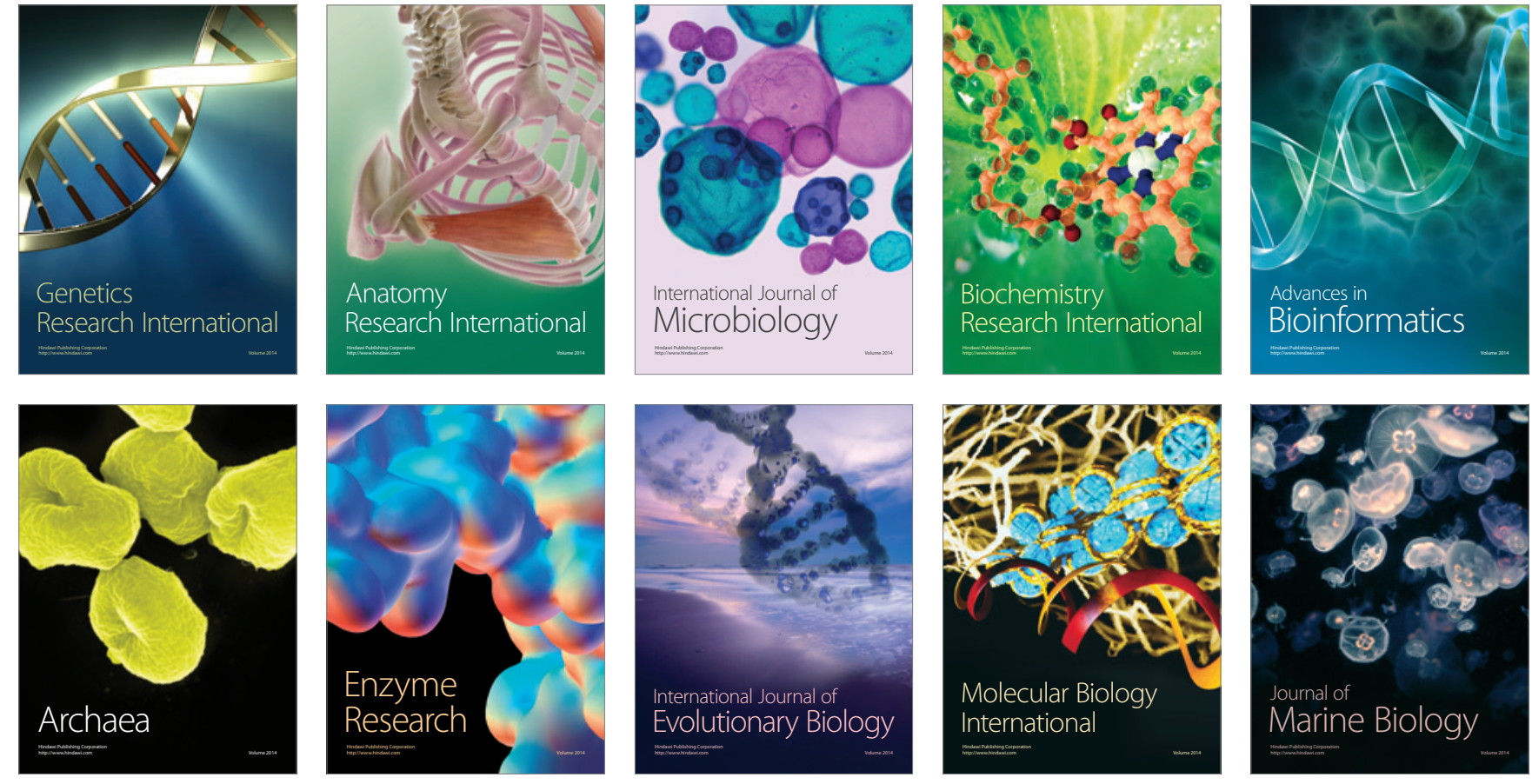